\title{
On the reactions of tertiary carbanions with some nitroindazoles and nitrobenzotriazoles
}

\author{
Marek K. Bernard*, Jacek Kujawski, Urszula Skierska, Andrzej K. Gzella, \\ and Wojciech Jankowski \\ Department of Organic Chemistry, Poznań University of Medical Sciences, \\ ul. Grunwaldzka 6, 60-780 \\ E-mail: mbernard@ump.edu.pl
}

\begin{abstract}
The vicarious nucleophilic substitution in some nitroindazole and nitrobenzotriazole derivatives with tertiary carbanions leads almost exclusively to products substituted para to the nitro group. As results from the theoretical calculations and structural evidences, such reaction outcome is due mainly to the stereoelectronic reasons in combination with the considerable shortening of the $\mathrm{C}_{\text {ortho }}-\mathrm{CNO}_{2}$ bond. The presence of the chiral and prochiral centres (the methine and $\mathrm{N}$ methylene groups, respectively) often gives rise to additional splitting of the methylene protons signal that is transmitted on a long distance provided there is no pyridinic nitrogen in the pathway of coupling.
\end{abstract}

Keywords: Indazoles, benzotriazoles, vicarious nucleophilic substitution, tertiary carbanions

\section{Introduction}

Ortho-substituted nitroarenes are useful starting materials for the synthesis of many heterocyclic compounds. One of the most practical methods that lead to the ortho-substituted derivatives of nitroarenes is the vicarious nucleophilic substitution (VNS). The VNS is a two-step reaction consisted in the addition of a carbanion, containing a leaving group $\mathrm{X}$ at the carbanionic centre, to a nitroarene followed by the base-induced $\beta$-elimination of $\mathrm{HX}$ from the $\delta^{\mathrm{H}}$-adduct formed in the first step. ${ }^{1}$ The reaction is the best practical method that allow introduction of a new substituent into an azole or benzazole ring by using nucleophilic reagents. ${ }^{2,3}$ The VNS products with a functional alkyl substituent ortho to the nitro group are particularly useful for the synthesis of indole and quinoline derivatives. ${ }^{1,4,5}$ Some VNS products are useful starting materials for the synthesis of biologically active compounds, like recently reported potent and selective $5-\mathrm{HT}_{6}$ antagonists. ${ }^{6}$ We employed such VNS products to the synthesis of indazole and condensed pyrazole derivatives that showed promising anticancer activity and were screened for 
anxiolytic effect. ${ }^{7,8}$ However, in the synthesis of some ortho-substituted nitroderivatives, we encountered severe problems when using tertiary carbanions or secondary carbanions containing poorer leaving groups than the chloride or thiophenoxide ions. ${ }^{9,10}$ In this paper we report our findings concerning the factors responsible for the VNS orientation in some nitrobenzazoles. Our results bear some relationship with those about the electrophilicity of nitroarenes and nitrohetroarenes published recently by the Mąkosza group. ${ }^{11,12}$

\section{Results and Discussion}

The starting materials for the reactions described in the next paragraph were obtained by ethylation of nitroindazoles $\mathbf{1 , 5}$, and 7, as well as 4-nitrobenzotriazole $\mathbf{1 0}$ (Scheme 1).

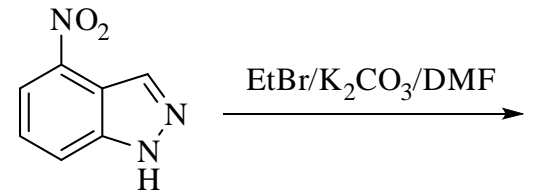

1

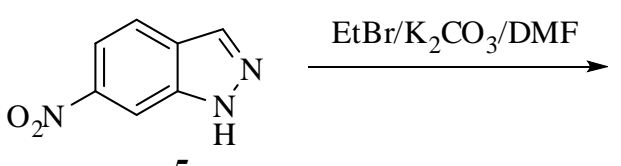

5<smiles>CCOC(=O)CC(C)(CC)C(=O)OCC</smiles><smiles>CCOC(=O)C(C)(C)C</smiles>

10<smiles></smiles>

3, $38 \%$<smiles></smiles>

6, $29 \%$<smiles>CCn1cc2cccc([N+](=O)[O-])c2n1</smiles>

4, $14 \%$<smiles></smiles><smiles>CCn1cc2cccc([N+](=O)[O-])c2n1</smiles><smiles></smiles>

11, $12 \%$<smiles>CCn1nc2cccc([N+](=O)[O-])c2n1</smiles>

12, $38 \%$<smiles>O=[N+]([O-])c1cccc2nn[nH]c12</smiles>

$\lfloor\mathrm{H}]$<smiles>CCn1nnc2cccc(N)c21</smiles>

14, $52 \%$

\section{Scheme 1}


The structures of benzotriazole derivatives 11-13 were confirmed by comparison of their ${ }^{1} \mathrm{H}$ and ${ }^{13} \mathrm{C}$ NMR spectra with the spectra for the corresponding N-methyl derivatives ${ }^{13}$ and the NOE difference experiment performed for the amino derivative 14; the latter was obtained by hydrogenation of $\mathbf{1 3}$ (Scheme 1). Irradiation of the amino protons resulted in enhancements of the neighbouring signals, namely 6-H doublet of doublets, $\mathrm{CH}_{2}$ quartet and $\mathrm{CH}_{3}$ triplet.
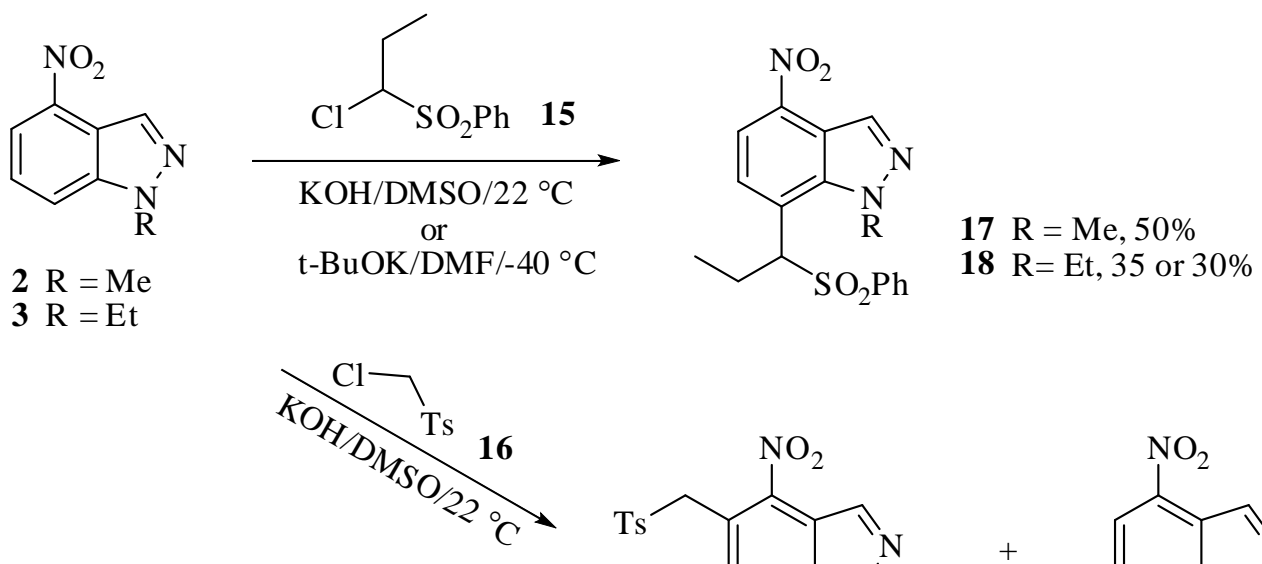<smiles>O=[N+]([O-])c1ccc(C[125I])c2cn[nH]c12</smiles><smiles>O=[N+]([O-])c1cccc2n[n-]cc12</smiles><smiles>CCC(Cl)S(=O)(=O)c1ccccc1</smiles><smiles>CCC(c1ccc2n[nH]cc2c1[N+](=O)[O-])S(=O)(=O)Oc1ccccc1</smiles>

21, $25 \%$

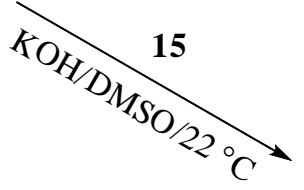<smiles>CCC(c1ccc([N+](=O)[O-])c2cn(CC)nc12)S(=O)(=O)c1ccccc1</smiles>

22, $49 \%$<smiles>CCn1ncc2cccc([N+](=O)[O-])c21</smiles>

8

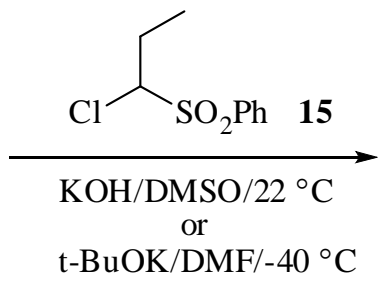

$\mathrm{t}-\mathrm{BuOK} / \mathrm{DMF} /-40{ }^{\circ} \mathrm{C}$<smiles></smiles>

23, 40 or $31 \%$

\section{Scheme 2}


In one of our initial experiments, we tried to obtain an ortho-substituted 4-nitroindazole derivative 18. Under the typical for ortho substitution conditions, i.e. t-BuOK as a soluble base, DMF as a solvent and low temperature $\left(-45^{\circ} \mathrm{C}\right),{ }^{1}$ the synthesis led to a single isolable product (Scheme 2) but the reaction mixture contained a significant amount of tars. With only the ${ }^{1} \mathrm{H}$ NMR spectrum at hand, we were convinced that compound $\mathbf{1 8}$ was the desired ortho isomer. However, when the reaction was repeated under the conditions favourable for the para orientation (KOH/DMSO at room temperature), its outcome was identical.

The ${ }^{1} \mathrm{H}$ NMR spectrum of compound 18 (Figure 1) displays several signals in the aromatic region confirming the disubstituted benzene part of the indazole ring, namely a singlet at 8.58 ppm for the 3-H proton, a doublet at $8.20 \mathrm{ppm}$ for the 5-H proton and two multiplets between 7.57 and $7.78 \mathrm{ppm}$ for the $\mathrm{PhSO}_{2}$ group; the latter multiplet overlaps with the doublet for the remaining 6-H proton. The coupling constant for the doublet at $8.20 \mathrm{ppm}\left({ }^{3} \mathrm{~J} 8.2 \mathrm{~Hz}\right)$ could not be conclusive whether the benzene part of the indazole ring is ortho- or para-substituted, thus we decided to register a NOE difference spectrum. Irradiation of the methine proton at $5.22 \mathrm{ppm}$, gave a significant $\mathrm{NOE}$ on the $\mathrm{N}-\mathrm{CH}_{2}$ protons at 4.57-4.77 ppm as well as on the $\mathrm{CH}-\mathrm{CH}_{2}$ (2.24$2.33 \mathrm{ppm})$ and $\mathrm{C}-\mathrm{CH}_{2} \mathbf{C H}_{3}(0.82 \mathrm{ppm})$ protons. A weak enhancement of the $\mathrm{CH}_{3}$ triplet of the $\mathrm{N}$ ethyl group (1.43 ppm) was also observed. This clearly shows that the methine proton and $\mathrm{N}$ ethyl group are in close proximity and the benzene ring is para-substituted. The signal for the N$\mathrm{CH}_{2}$ protons is particularly interesting due to its atypical splitting: instead of the expected quartet it appears as a complex multiplet (Figure 1). Also the methine signal is observed as a triplet with some residual splitting instead of a doublet of doublets. A part of the mystery was resolved by registering the NMR spectra for $\mathbf{1 8}$ at higher temperatures (Figure 2). At $60{ }^{\circ} \mathrm{C}$ the signal for methine proton appeared as a doublet of doublets and several lines disappeared from the complex $\mathrm{N}-\mathrm{CH}_{2}$ multiplet. The latter one was then observed as a clean nonet. The unusual splitting of the $\mathrm{N}-\mathrm{CH}_{2}$ signal is thus due to two factors: (i) hindered rotation and (ii) the presence of the chiral centre (the methine proton) in close proximity. The latter factor renders the $\mathrm{N}$-methylene protons diastereotopic and not equivalent, and therefore they exhibit further splittings as they couple to each other.

To verify such reasoning, we obtained several indazole and benzotriazole derivatives with or without the chiral centre (Schemes 2 and 3).

Similarly to the starting material $\mathbf{3}$, the VNS in 1-methyl-4-nitroindazole (2) using the carbanion precursor 15 led to a single product 17 (Scheme 2) whereas, as expected, the reaction of compound 3 with 16 gave two isomers 19 and 20. Compound 17 as well as isomers 19 and 20 contain neither prochiral methylene protons (17) nor a chiral centre (19 and 20). A normal singlet is observed for the $\mathrm{N}$-methyl group in $\mathbf{1 7}$ and a typical quartet is seen for the methylene protons both in $\mathbf{1 9}$ and $\mathbf{2 0 .}$ 
(a) compound $\mathbf{1 8}$

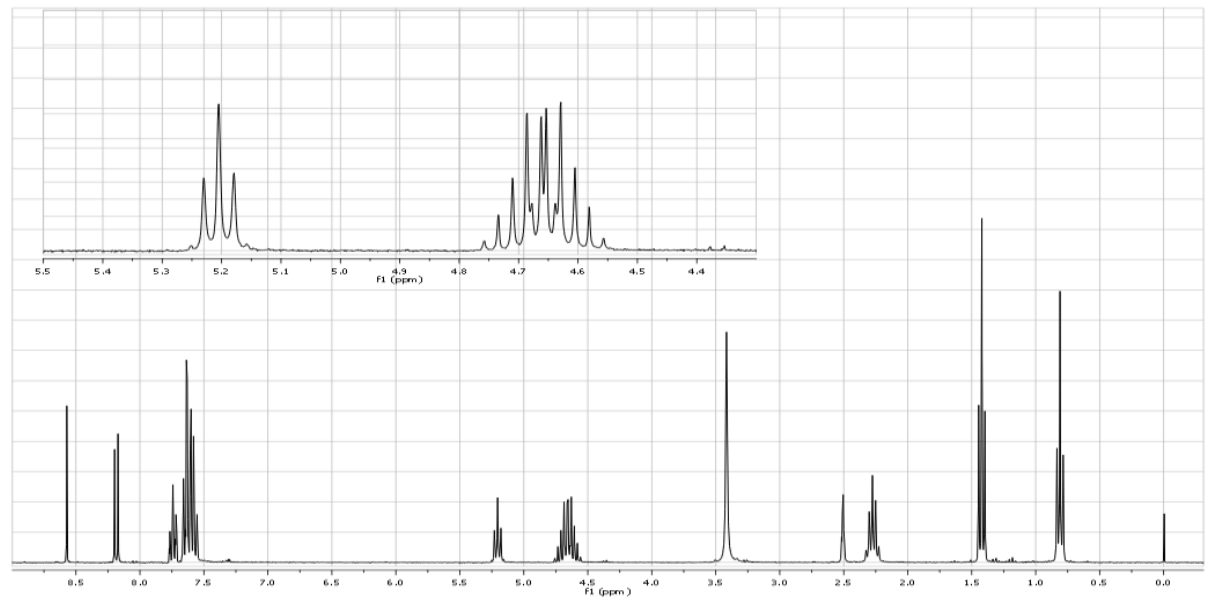

(b) compound 26

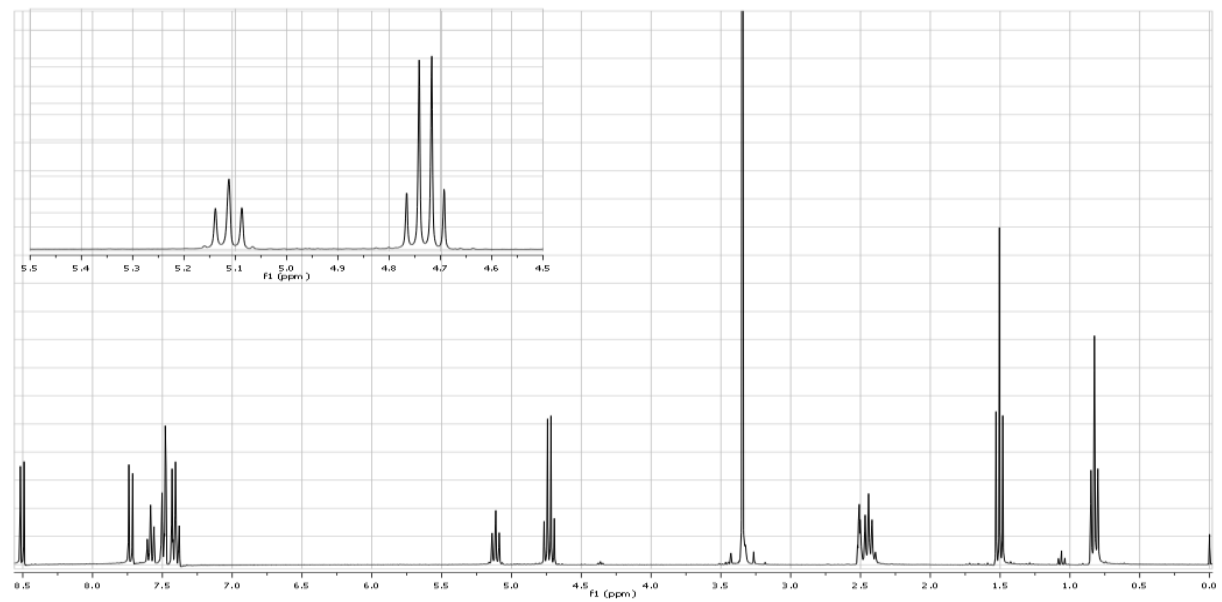

Figure 1. Examples of the ${ }^{1} \mathrm{H}$ NMR spectra with expanded regions containing the signals for methine and N-methylene protons: (a) revealing the interaction between the chiral and prochiral centres; (b) devoid of this interaction due to suppression by the pyridinic nitrogen.

Only the para isomer 22 was detected and isolated from the reaction mixture containing compounds 4 and $\mathbf{1 5}$ as starting materials and KOH/DMSO as a base/solvent system (Scheme 2). Its ${ }^{1} \mathrm{H}$ NMR spectrum shows a similar pattern concerning the signals for the N-methylene protons like that for compound 18, i.e. a symmetrical multiplet, consisting this time of ten lines, instead of a typical quartet. However, in contrast to compounds $\mathbf{2}$ and $\mathbf{3}$, the starting material 4 gave two isomers 21 and 22 when treated with the carbanion precursor $\mathbf{1 5}$ in t-BuOK/DMF at low temperature (Scheme 2). Moreover, the ortho isomer 21 was the major product of the reaction: $25 \%$ vs. $10 \%$ for isomer 22 . Such change in the VNS orientation is primarily caused by the presence of the peri unshared electron pair on the nitrogen atom N1. This electron pair retards both the approach of the carbanion to position 7 and the base attack in the elimination step, and thus forces the VNS at position 5. It is noteworthy that the ${ }^{1} \mathrm{H}$ NMR spectrum of 21 
reveals an identical multiplet for the $\mathrm{N}$-methylene protons like for the para isomer $\mathbf{2 2}$ regardless of the fact that the distance between these protons and the chiral centre is quite long.
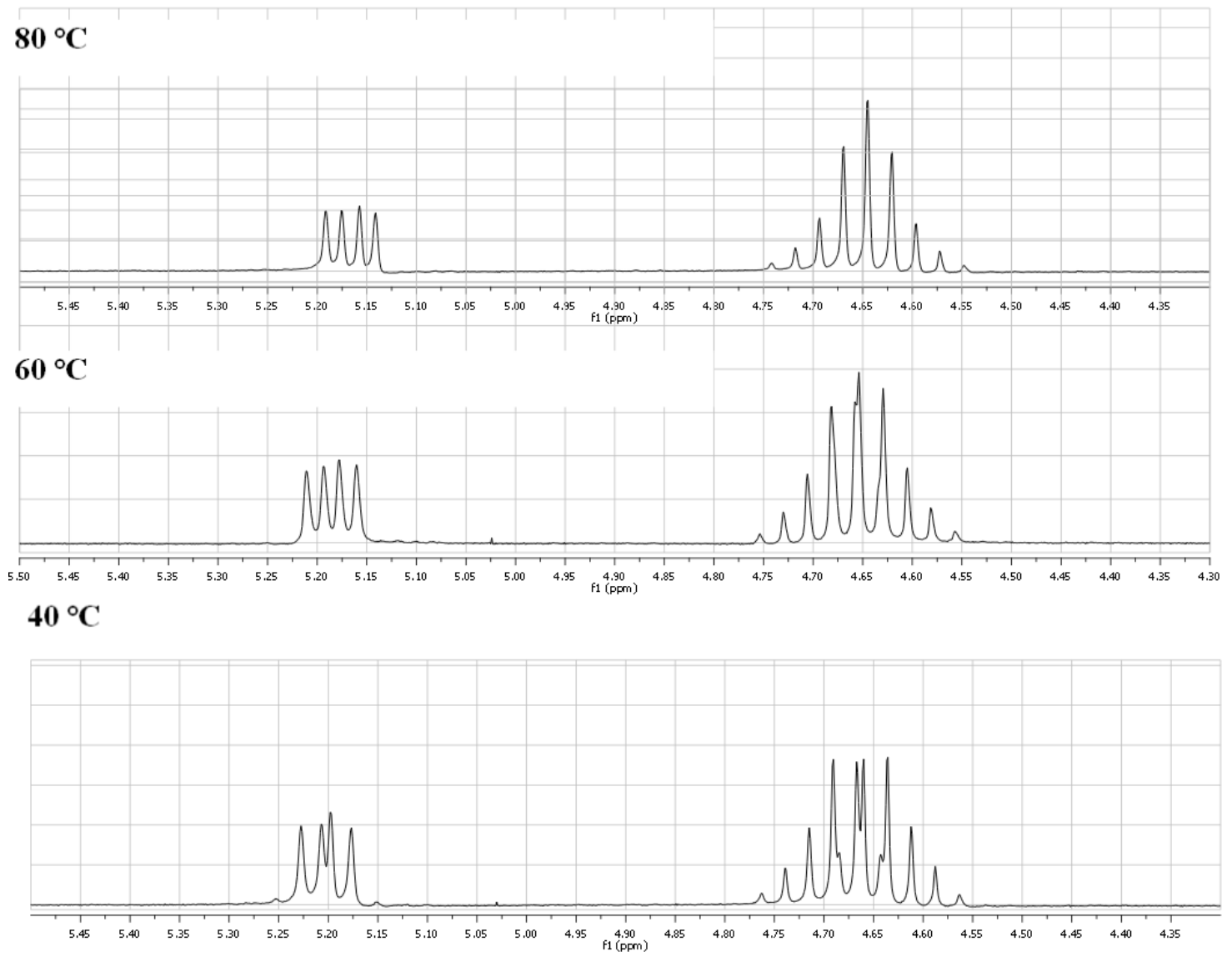

Figure 2. The ${ }^{1} \mathrm{H}$ NMR spectra for compound 18 registered at 40,60 , and $80{ }^{\circ} \mathrm{C}$, showing signals for the methine proton and $\mathrm{N}$-methylene protons (the spectrum recorded at ambient temperature is shown in Figure 1a).

The VNS reaction of compound $\mathbf{6}$ with $\mathbf{1 5}$ did not lead to any isolable product. Despite using a variety of reaction conditions, we were able to recover only the starting material $6(32-57 \%)$ from the reaction mixtures that contained usually significant quantities of tarry products. The most apparent rationale for the reaction failure is the stereoelectronic hindrance caused by the nitro group and unshared electron pair at $\mathrm{N} 1$, both in close proximity to the reaction site.

Likewise reactant $\mathbf{3}$, compound $\mathbf{8}$ gave only the para substituted product $\mathbf{2 3}$ regardless of the conditions applied (Scheme 2). Strikingly, in the ${ }^{1} \mathrm{H}$ NMR spectrum of 23, the signal for $\mathrm{N}-\mathrm{CH}_{2}$ protons appears as a typical quartet rather than a complex multiplet as opposed to the $\mathrm{N}-\mathrm{CH}_{2}$ signals for indazoles 18, 21, and 22 described above (albeit some residual lines can be seen within this quartet), and the same signal in the spectrum of benzotriazole 24. The latter compound was the sole product obtained from the reaction of nitrobenzotriazole $\mathbf{1 1}$ with the 
carbanion precursor 15 in both base/solvent systems (Scheme 3). In its ${ }^{1} \mathrm{H}$ NMR spectrum, an AB system - doublets at 7.72 and $8.33 \mathrm{ppm}$ with ortho coupling ${ }^{3} \mathrm{~J} 8.4 \mathrm{~Hz}$ - indicates a parasubstituted benzene ring in benzotriazole rather than ortho as the coupling constant for the latter is substantially larger and close to $9 \mathrm{~Hz} .{ }^{14}$ The ${ }^{1} \mathrm{H}$ NMR spectrum of 24 shows similar diastereotopism like the spectra for indazoles $\mathbf{1 8}, \mathbf{2 1}$, and 22, i.e. the $\mathrm{N}$-methylene protons signal takes shape of a symmetrical multiplet, this time consisting of 12 lines. The difference in number of lines present in the multiplets for $\mathrm{N}$-methylene protons in compounds 18, 21, 22, and 24 may be due not only to the hindered rotation (compound 18) but also to overlapping of some lines within the multiplets.<smiles>CCn1nnc2c([N+](=O)[O-])cccc21</smiles>

11

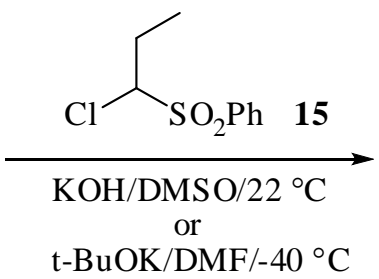

t-BuOK/DMF/ $-40^{\circ} \mathrm{C}$<smiles></smiles>

$\mathbf{2 4}, 46$ or $35 \%$<smiles>CCn1nc2cccc([N+](=O)[O-])c2n1</smiles>

12<smiles>CCn1nnc2cccc([N+](=O)[O-])c21</smiles>

13

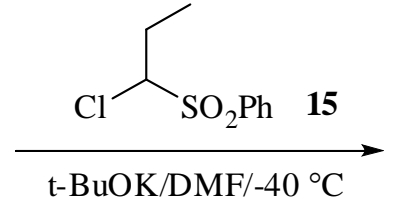

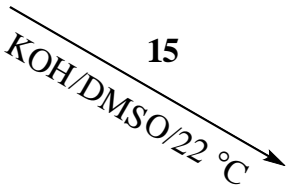<smiles>CCC(c1ccccc1)c1ccc2n[nH]nc2c1[N+](=O)[O-]</smiles>

$25,38 \%$<smiles>CCC(c1ccccc1)c1ccc([N+](=O)[O-])c2n[nH]cc12</smiles>

26, $55 \%$

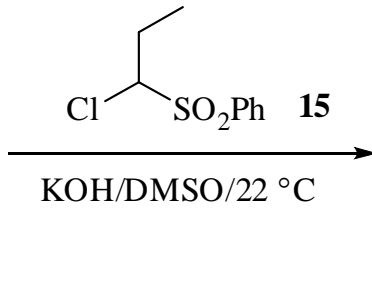<smiles></smiles>

$27,59 \%$<smiles>CCC(c1ccccc1)c1ccc([N+](=O)[O-])c2n[nH]cc12</smiles>

26, $21 \%$ (f rom NMR)

\section{Scheme 3}

The effect of diastereotopic N-methylene protons is not observed for other benzotriazole derivatives 25-27 (Figure 1) obtained by the VNS from starting materials 12 and $\mathbf{1 3}$ (Scheme 3, we were unable to isolate an analytically pure sample of $\mathbf{2 6}$ but the ${ }^{1} \mathrm{H}$ NMR of the reaction 
mixture showed its presence in an about $21 \%$ yield). In the ${ }^{1} \mathrm{H}$ NMR spectra registered for compounds 25-27, the signal for these protons appears as a typical quartet.

The suppression of the additional splitting of $\mathrm{N}$-methylene signal in the spectra of benzotriazole derivatives 25-27 is due to the presence of the pyridinic nitrogen N3 in the pathway of possible coupling. We tried to quantify the effect using theoretical calculations. Although we have not overly been successful, some of our findings are worthy of mention. The Natural Bond Orbitals (NBO) analysis showed the presence of a high-energy molecular Rydberg orbital RY* on N3 with the following contribution of atomic orbitals: s $2.17 \%, \mathrm{p} 93.10 \%$, and $\mathrm{d}$ $4.73 \%$. This analysis revealed also the presence of a two-centre Lewis orbital BD with a high occupancy value that connected atoms N2 and N3. The above features can be useful in the interpretation of the UV spectra of some benzotriazoles.

In summary, the presence of the chiral centre within a molecule of N-ethylindazole and $\mathrm{N}$ ethylbenzotriazole often gives rise to further splitting of the $\mathrm{N}$-methylene signal. The effect is transmitted through the $\pi$ system on a long distance, even through seven bonds (compound 21), provided that there is no pyridinic ring nitrogen in the way of possible coupling.

Table 1. The effective charges on atoms other than hydrogen in indazole and benzotriazole derivatives 3, 4 and 11, 12 calculated by the B3LYP/6-31G(d,p) method (CPCM/DMSO)

\begin{tabular}{ccccc}
\hline Atom & Indazole $\mathbf{3}$ & Indazole 4 & Benzotriazole 11 & Benzotriazole 12 \\
\hline $\mathrm{N} 1$ & -0.426 & -0.431 & -0.388 & -0.376 \\
$\mathrm{~N} 2$ & -0.282 & -0.243 & -0.049 & -0.013 \\
$\mathrm{C} 3$ & 0.111 & 0.130 & - & - \\
$\mathrm{N} 3$ & - & - & -0.418 & -0.405 \\
$\mathrm{C} 3 \mathrm{a}$ & -0.023 & -0.008 & 0.237 & 0.291 \\
$\mathrm{C} 4$ & 0.200 & 0.211 & 0.273 & 0.270 \\
$\mathrm{C} 5$ & -0.095 & -0.101 & -0.102 & -0.106 \\
$\mathrm{C} 6$ & -0.119 & -0.124 & -0.118 & -0.116 \\
$\mathrm{C} 7$ & -0.058 & -0.066 & -0.061 & -0.071 \\
$\mathrm{C} 7 \mathrm{a}$ & 0.362 & 0.278 & 0.350 & 0.248 \\
$\mathrm{~N}(\mathrm{nitro})$ & 0.377 & 0.372 & 0.372 & 0.372 \\
$\mathrm{O} 1$ & -0.400 & -0.436 & -0.426 & -0.432 \\
$\mathrm{O} 2$ & -0.409 & -0.443 & -0.419 & -0.426 \\
$\mathrm{C}\left(\mathrm{H}_{2}\right)$ & -0.020 & -0.057 & -0.071 & -0.052 \\
$\mathrm{C}\left(\mathrm{H}_{3}\right)$ & -0.356 & -0.323 & -0.324 & -0.326 \\
\hline
\end{tabular}

To determine which factors are responsible for the practical lack of the substitution ortho to nitro group in nitroindazoles and nitrobenzotriazoles, we referred to theoretical calculations and $\mathrm{X}$-ray crystallography. In nitroindazoles 3, 4 and nitrobenzotriazoles 11, 12, the charge distribution obtained by the calculations is characterized by a noticeable withdrawal of the electron density from the benzene ring into the nitro group (Table 1). The electrons tend to 
accumulate on the oxygen atoms and ring nitrogens. A particular low electron density is found on the carbons neighbouring the nitrogen atoms, i.e. the ipso carbon $\mathrm{C} 4$, bridge carbons $\mathrm{C} 7 \mathrm{a}$ and $\mathrm{C} 3 \mathrm{a}$ (the latter one only in benzotriazoles), and carbon C3 in indazoles. The calculations reveal small differences in charges between the ortho and para carbons, both in indazole and benzotriazole derivatives. Even though these dissimilarities, favouring the para positions by only 0.04 electrons, are not enough large to alter significantly the direction of carbanion attack, they may add some impact to the stereochemical discrimination between these positions described in the next paragraph.

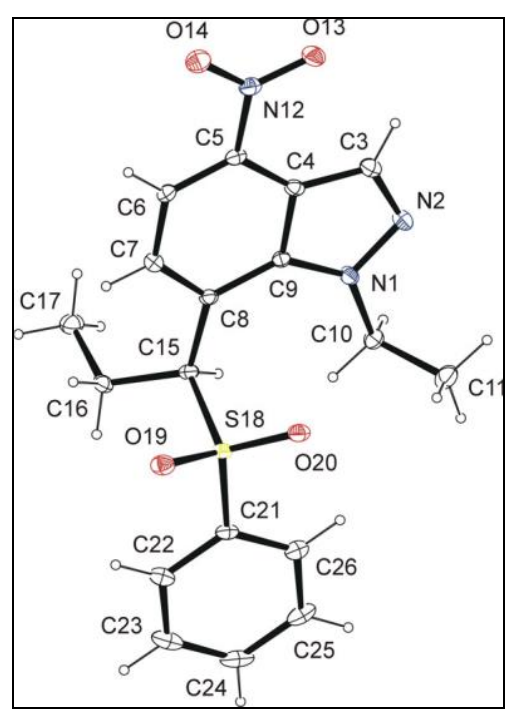

Figure 3. ORTEP view of 18. Ellipsoids are drawn at the 50\% probability level.

Figure 3 shows the X-ray structure of compound 18. As expected, the indazole ring is planar but the nitro group is not coplanar with the ring; it is twisted of the ring plane by $3.58^{\circ}$. The nitrobenzene ring of indazole derivative 18 reveals considerable deviations concerning some bonds in comparison with nitrobenzene. The C4-C5 bond is particularly short (1.35 ^ vs. 1.3989 $\AA$ in nitrobenzene ${ }^{15}$ ). As a similar value for the C4-C5 bond length can be predicted for nitroindazole $\mathbf{3}$, this bond shortening may be crucial for the orientation in the nucleophilic substitution. The other exo bond, namely C6-C7 is also significantly shorter than the C5-C6 endo bond (1.367 $\AA$ vs. $1.411 \AA$ ). This means that the antiperiplanar conformation required for the $\beta$ elimination is severely hindered in the ortho $\sigma^{\mathrm{H}}$ adduct, hence the ortho substitution involving bulky tertiary carbanions is usually not observed for nitroindazole derivatives even when the reaction is carried out under the conditions more favourable for the kinetic ortho product ( $\mathrm{t}$ $\mathrm{BuOK} / \mathrm{DMF} /$ low temperature). Only when using the 2-substituted nitrobenzazoles of dienoid structure 4 and $\mathbf{1 2}$ as starting materials, we were able to detect both ortho and para isomers in the reaction mixture (compounds 21 and 22 as well as 25 and 26). This change in the VNS orientation is mainly due to the stereoelectronic hindrance of the peri unshared electron pair on N1. 
a.

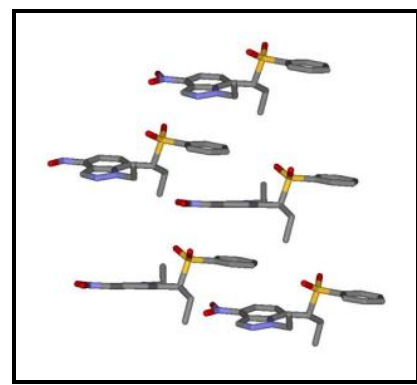

b.

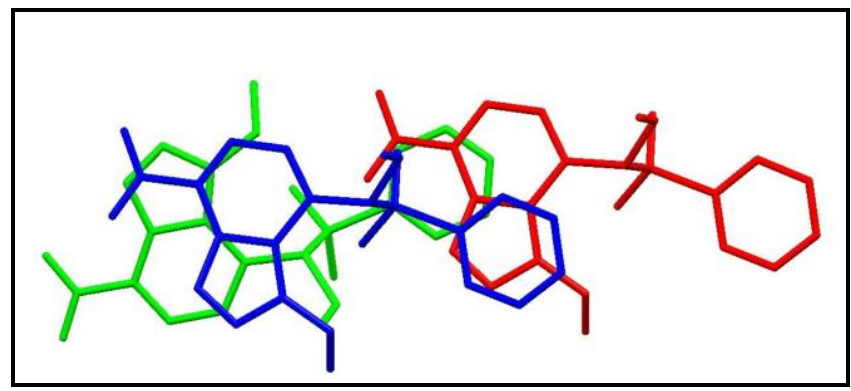

Figure 4. (a) Cross section through the stacks of 18 (hydrogen atoms are omitted). (b) Superimposition of pyrazole and benzene rings in the stacks.

The crystallographic structure of $\mathbf{1 8}$ reveals some interesting features. The hydrogen atoms ortho to the sulfonyl group are engaged in a weak intramolecular hydrogen bonds with the oxygen atoms of the sulfonyl group; the distances $\mathrm{C}_{\text {ortho }}-\mathrm{H}^{\cdots} \mathrm{OS}$ are 2.51 and $2.71 \AA$, respectively. Moreover, the oxygen atom O1S is an acceptor in the intermolecular hydrogen bond $\mathrm{C} 5-\mathrm{H} \cdots \mathrm{O} 1 \mathrm{~S}$ having the following parameters: $d=2.56 \AA, D=3.17 \AA$, and $\theta=124^{\circ}$. Another weak intermolecular hydrogen bond connects the $\mathrm{NO}_{2}$ oxygen atoms with the methine carbon and has the following parameters: $d=2.18 \AA, D=3.38 \AA$, and $\theta=152^{\circ}$. All values listed above fit perfectly within the limits for weak hydrogen bonds: $d=2.0-3.0 \AA, D=3.0-4.0 \AA$, and $\theta=90$ $180^{\circ} .{ }^{16}$ Worth mentioning is considerable lengthening of the bond between methine carbon and proton: $1.20 \AA$ in comparison with the standard length for a $\mathrm{Csp}^{3}-\mathrm{H}$ bond $-1.083 \AA{ }^{17}$ The intermolecular hydrogen bonds keep the molecules of $\mathbf{1 8}$ in a three-dimensional aggregation (Figure 4a). The unit cell contains four molecules. The indazole and phenyl rings from separate molecules are arranged alternatively forming infinite stacks. The extent of stacking is significant. Moreover, the stacking between the phenyl and pyrazole rings is considerably larger than the stacking between the phenyl and benzene rings (Figure 4b). Both above depicted interactions the weak hydrogen bonding and $\pi-\pi$ stacking - may have an important value in the molecular recognition involving indazole ring.

\section{Experimental Section}

General. Flash chromatography (FC) was performed using silica gel 60, 230-400 mesh (Merck), Low Pressure Liquid Chromatography (LPLC) - the Michael-Miller system and 15-40 silica gel (Merck), gradient chromatography - silica gel 60, 60-230 mesh (Merck). Melting points were determined on a Boetius apparatus and are uncorrected. ${ }^{1} \mathrm{H}$ NMR were recorded at 300 (Varian Mercury 300), 400 (Varian VNMR-S), or $600 \mathrm{MHz}$ (Bruker Avance 600) in DMSO-d 6 with TMS as an internal standard. When necessary, the position of the phenylsulfonyl substituent attachment at the hetarene ring was proved by NOE differential spectra. ${ }^{13} \mathrm{C}$ NMR spectra were registered at 100 or $150 \mathrm{MHz}$ using Varian VNMR-S or Bruker Avance 600 spectrometers, 
respectively. Low resolution mass spectra were recorded on an AMD Intectra Mass AMD 402 instrument operating at $75 \mathrm{eV}$. IR spectra were run in $\mathrm{KBr}$ on a Specord 75-IR apparatus. Elemental analyses were performed on a Vario EL III instrument. Starting materials, apart from those described below, were obtained by known procedures $\left(2^{18}, \mathbf{1 5}\right.$ and $\left.16^{19}\right)$ or were commercially available.

Alkylation of nitroindazoles. A mixture of 4- or 6- or 7-nitroindazole (1 or 5 or 7) (4.9 g, 30 $\mathrm{mmol}$ ), bromoethane $(3.5 \mathrm{~g}, 32 \mathrm{mmol})$ and finely powdered $\mathrm{K}_{2} \mathrm{CO}_{3}(14 \mathrm{~g})$ was stirred vigorously in DMF (60 mL) at room temperature for 75 (compound 1), 60 (compound 5) or 120 (compound 7) minutes. The reaction mixture was filtered and the solvent was removed under reduced pressure. The residue was treated with water and the products were isolated as described below.

1-Ethyl-4-nitro- $\mathbf{H}$-indazole (3) and 2-ethyl-4-nitro- $\mathbf{H}$-indazole (4). The resulted yellow precipitate was filtered off. The solid was dried and crystallized twice from methanol to yield $1.55 \mathrm{~g}$ of compound 3 as orange plates, mp $107-109{ }^{\circ} \mathrm{C} .{ }^{1} \mathrm{H}$ NMR $(300 \mathrm{MHz}): \delta 1.45\left(\mathrm{t},{ }^{3} \mathrm{~J} 7.5\right.$ $\left.\mathrm{Hz}, 3 \mathrm{H}, \mathrm{CH}_{3}\right), 4.59\left(\mathrm{q},{ }^{3} \mathrm{~J} 7.5 \mathrm{~Hz}, 2 \mathrm{H}, \mathrm{CH}_{2}\right), 7.66\left(\mathrm{dd},{ }^{3} J_{67} 8.2 \mathrm{~Hz},{ }^{3} J_{56} 7.7 \mathrm{~Hz}, 1 \mathrm{H}, 6-\mathrm{H}\right), 8.19$ (dd, $\left.{ }^{3} J_{56} 7.7 \mathrm{~Hz},{ }^{4} J_{57} 0.5 \mathrm{~Hz}, 1 \mathrm{H}, 5-\mathrm{H}\right), 8.31\left(\mathrm{dd},{ }^{3} J_{67} 8.2 \mathrm{~Hz},{ }^{5} J_{37} 0.8 \mathrm{~Hz}, 1 \mathrm{H}, 7-\mathrm{H}\right), 8.52\left(\mathrm{~d},{ }^{5} J_{37} 0.8\right.$ $\mathrm{Hz}, 1 \mathrm{H}, 3-\mathrm{H}) .{ }^{13} \mathrm{C}$ NMR $(100 \mathrm{MHz}): \delta 14.9\left(\mathrm{CH}_{3}\right), 43.8\left(\mathrm{CH}_{2}\right), 115.8,117.9,118.4,125.6,131.4$, 139.6, 140.4. Anal. Calcd for $\mathrm{C}_{9} \mathrm{H}_{9} \mathrm{~N}_{3} \mathrm{O}_{2}$ (191.18): C, 56.54; H, 4.74; N, 21.98\%. Found: C, $56.37 ; \mathrm{H}, 4.85 ; \mathrm{N}, 22.01 \%$.

The solution from crystallization was evaporated to dryness and the residue was flashchromatographed twice using benzene - ethyl acetate $10: 1$ as an eluent to yield $0.65 \mathrm{~g}$ of compound 3, mp $107-109^{\circ} \mathrm{C}$ (methanol) (total yield: $2.20 \mathrm{~g}, 38 \%$ ) and $0.83 \mathrm{~g}(14 \%)$ of 2-ethyl4-nitroindazole (4) as yellow prisms, mp 78-79 ${ }^{\circ} \mathrm{C}$ (methanol) (lit. ${ }^{20} 75-77^{\circ} \mathrm{C}$ ). ${ }^{1} \mathrm{H}$ NMR (300 $\mathrm{MHz}): \delta 1.56\left(\mathrm{t},{ }^{3} \mathrm{~J} 7.2 \mathrm{~Hz}, 3 \mathrm{H}, \mathrm{CH}_{3}\right), 4.61\left(\mathrm{q},{ }^{3} \mathrm{~J} 7.2 \mathrm{~Hz}, 2 \mathrm{H}, \mathrm{CH}_{2}\right), 7.50\left(\mathrm{dd},{ }^{3} J_{67} 8.5 \mathrm{~Hz},{ }^{3} J_{56} 7.7\right.$ $\mathrm{Hz}, 1 \mathrm{H}, 6-\mathrm{H}), 8.20\left(\mathrm{dd},{ }^{3} J_{56} 7.7 \mathrm{~Hz},{ }^{4} J_{57} 0.5 \mathrm{~Hz}, 1 \mathrm{H}, 5-\mathrm{H}\right), 8.21\left(\mathrm{dd},{ }^{3} J_{67} 8.5 \mathrm{~Hz},{ }^{4} J_{57} 0.5 \mathrm{~Hz}, 1 \mathrm{H}\right.$, 7-H), 8.92 (s, $1 \mathrm{H}, 3-\mathrm{H}) .{ }^{13} \mathrm{C}$ NMR $(100 \mathrm{MHz}): \delta 15.7\left(\mathrm{CH}_{3}\right), 48.4\left(\mathrm{CH}_{2}\right), 113.9,120.3,124.2$, 124.3, 126.2, 140.0, 149.1.

2-Ethyl-6-nitro- $2 \mathrm{H}$-indazole (6). The resulted yellow precipitate was crystallized twice from methanol to give $1.67 \mathrm{~g}(29 \%)$ of compound 6 as yellow needles, mp 97-98 ${ }^{\circ} \mathrm{C} .{ }^{1} \mathrm{H}$ NMR (300 MHz): $\delta 1.43\left(\mathrm{t},{ }^{3} J 7.2 \mathrm{~Hz}, 3 \mathrm{H}, \mathrm{CH}_{3}\right), 4.62\left(\mathrm{q},{ }^{3} J 7.2 \mathrm{~Hz}, 2 \mathrm{H}, \mathrm{CH}_{2}\right), 7.95\left(\mathrm{dd},{ }^{3} J_{45} 8.8 \mathrm{~Hz},{ }^{4} J_{34} 1.9\right.$ $\mathrm{Hz}, 1 \mathrm{H}, 4-\mathrm{H}), 8.02\left(\mathrm{dd},{ }^{3} J_{45} 8.8 \mathrm{~Hz},{ }^{4} J_{57} 0.7 \mathrm{~Hz}, 1 \mathrm{H}, 5-\mathrm{H}\right), 8.32\left(\mathrm{~d},{ }^{4} J_{57} 0.7 \mathrm{~Hz}, 1 \mathrm{H}, 7-\mathrm{H}\right), 8.76-$ $8.78(\mathrm{~m}, 1 \mathrm{H}, 3-\mathrm{H}) .{ }^{13} \mathrm{C} \mathrm{NMR}(100 \mathrm{MHz}): \delta 14.9\left(\mathrm{CH}_{3}\right), 43.6\left(\mathrm{CH}_{2}\right), 106.7,114.7,122.1,126.5$, 133.3, 137.4, 145.8. Anal. Calcd for $\mathrm{C}_{9} \mathrm{H}_{9} \mathrm{~N}_{3} \mathrm{O}_{2}$ (191.18): C, 56.54; H, 4.74; N, 21.98\%. Found: C, 56.74; H, 4.80; N, 21.69\%.

The filtrate from crystallization contained a mixture of compound $\mathbf{6}$ and its 1-ethyl isomer that was not further separated.

1-Ethyl-7-nitro- $1 \mathrm{H}$-indazole (8) and 2-ethyl-7-nitro-2H-indazole (9). The resulted yellow precipitate was flash-chromatographed using hexanes - ethyl acetate $5: 1$ as an eluent. The first fraction, after crystallization from dilute methanol, gave $2.11 \mathrm{~g}$ (37\%) of compound $\mathbf{8}$ as yellow needles, mp 71-72 ${ }^{\circ} \mathrm{C} .{ }^{1} \mathrm{H}$ NMR (300 MHz): $\delta 1.55\left(\mathrm{t},{ }^{3} \mathrm{~J} 7.1 \mathrm{~Hz}, 3 \mathrm{H}, \mathrm{CH}_{3}\right), 4.52\left(\mathrm{q},{ }^{3} \mathrm{~J} 7.1 \mathrm{~Hz}\right.$, 
$\left.2 \mathrm{H}, \mathrm{CH}_{2}\right), 7.35\left(\mathrm{dd},{ }^{3} J_{45} 8.0 \mathrm{~Hz},{ }^{3} J_{56} 7.7 \mathrm{~Hz}, 1 \mathrm{H}, 5-\mathrm{H}\right), 8.20\left(\mathrm{dd},{ }^{3} J_{56} 7.7 \mathrm{~Hz},{ }^{4} J_{46} 0.8 \mathrm{~Hz}, 1 \mathrm{H}, 6-\right.$ $\mathrm{H}), 8.26\left(\mathrm{dd},{ }^{3} J_{45} 8.0 \mathrm{~Hz},{ }^{4} J_{46} 0.8 \mathrm{~Hz}, 1 \mathrm{H}, 4-\mathrm{H}\right), 8.44$ (s, 1H, 3-H). ${ }^{13} \mathrm{C} \mathrm{NMR}(100 \mathrm{MHz}): \delta 15.3$ $\left(\mathrm{CH}_{3}\right), 47.3\left(\mathrm{CH}_{2}\right), 120.1,124.6,128.5,128.7,129.4$, 134.8, 134.9. Anal. Calcd for $\mathrm{C}_{9} \mathrm{H}_{9} \mathrm{~N}_{3} \mathrm{O}_{2}$ (191.18): C, 56.54; H, 4.74; N, 21.98\%. Found: C, 56.27; H, 4.63; N, 22.23\%.

The second fraction was further flash-chromatographed using benzene - ethyl acetate $10: 1$ as an eluent. The separation resulted in recovery of the starting material 7: $0.98 \mathrm{~g}$ (20\%), mp 188$189{ }^{\circ} \mathrm{C}$ (lit. ${ }^{21} \mathrm{mp} 186.5-187.5^{\circ} \mathrm{C}$ ). The third fraction was flash-chromatographed using hexanes ethyl acetate $2: 1$ as an eluent. Crystallization from methanol gave $1.12 \mathrm{~g}$ (20\%) of 2-ethyl-7nitroindazole (9) as yellow plates, mp 80-81 ${ }^{\circ} \mathrm{C}$ (lit. $\left.{ }^{18} 74-76{ }^{\circ} \mathrm{C}\right) .{ }^{1} \mathrm{H}$ NMR $(300 \mathrm{MHz}): \delta 1.56(\mathrm{t}$, $\left.{ }^{3} J 7.4 \mathrm{~Hz}, 3 \mathrm{H}, \mathrm{CH}_{3}\right), 4.58$ (q, ${ }^{3} J 7.4 \mathrm{~Hz}, 2 \mathrm{H}, \mathrm{CH}_{2}$ ), 7.26 (dd, $\left.{ }^{3} J_{45} 8.2 \mathrm{~Hz},{ }^{3} J_{56} 7.7 \mathrm{~Hz}, 1 \mathrm{H}, 5-\mathrm{H}\right)$, $8.27\left(\mathrm{dd},{ }^{3} J_{45} 8.2 \mathrm{~Hz},{ }^{4} J_{46} 0.8 \mathrm{~Hz}, 1 \mathrm{H}, 4-\mathrm{H}\right), 8.31\left(\mathrm{dd},{ }^{3} J_{56} 7.7 \mathrm{~Hz},{ }^{4} J_{46} 0.8 \mathrm{~Hz}, 1 \mathrm{H}, 6-\mathrm{H}\right), 8.82$ (s, $1 \mathrm{H}, 3-\mathrm{H}) .{ }^{13} \mathrm{C}$ NMR $(100 \mathrm{MHz}): \delta 15.6\left(\mathrm{CH}_{3}\right), 48.4\left(\mathrm{CH}_{2}\right), 119.6,124.6,125.2,126.3,129.9$, $136.5,139.4$.

Alkylation of 4-nitro-1H-benzotriazole (10). A mixture of 4-nitro- $1 H$-benzotriazole (10) (2.46 $\mathrm{g}$, $15 \mathrm{mmol})$, bromoethane $(1.96 \mathrm{~g}, 18 \mathrm{mmol})$, finely powdered $\mathrm{K}_{2} \mathrm{CO}_{3}(7.0 \mathrm{~g})$, and tetrabutylammonium bromide $(50 \mathrm{mg})$ was stirred vigorously in DMF $(30 \mathrm{~mL})$ at $40{ }^{\circ} \mathrm{C}$ for 90 minutes. The reaction mixture was diluted with water $(200 \mathrm{~mL})$ and the resulted precipitate was filtered off (solid A). The filtrate was extracted with dichloromethane ( $3 \times 20 \mathrm{~mL})$, the combined organic layers were washed with water and dried over $\mathrm{MgSO}_{4}$. The solvent was distilled off to give solid B as yellow crystals. Solid A consisted of two isomers while solid B contained, apart from these isomers, also a third compound.

Solid A was treated with concd $\mathrm{HCl}(50 \mathrm{~mL})$ and the resulted suspension was stirred at room temperature for 30 minutes. The insoluble part was filtered off and crystallized from ethanol to give $0.52 \mathrm{~g}$ of 2-ethyl-4-nitro- $2 \mathrm{H}$-benzotriazole (12) as yellow plates, mp 101-102 ${ }^{\circ} \mathrm{C}$. ${ }^{1} \mathrm{H} \mathrm{NMR}$ (400 MHz): $\delta 1.66\left(\mathrm{t},{ }^{3} J 7.3 \mathrm{~Hz}, 3 \mathrm{H}, \mathrm{CH}_{3}\right), 4.93\left(\mathrm{q},{ }^{3} J 7.3 \mathrm{~Hz}, 2 \mathrm{H}, \mathrm{CH}_{2}\right), 7.68$ (dd, ${ }^{3} J_{67} 8.5 \mathrm{~Hz}$, $\left.{ }^{3} J_{56} 7.7 \mathrm{~Hz}, 1 \mathrm{H}, 6-\mathrm{H}\right), 8.46\left(\mathrm{dd},{ }^{3} J_{56} 7.7 \mathrm{~Hz},{ }^{4} J_{57} 0.8 \mathrm{~Hz}, 1 \mathrm{H}, 5-\mathrm{H}\right), 8.49\left(\mathrm{dd},{ }^{3} J_{67} 8.5 \mathrm{~Hz}, 1 \mathrm{H},{ }^{4} J_{57}\right.$ $0.8 \mathrm{~Hz}, 7-\mathrm{H}) .{ }^{13} \mathrm{C}$ NMR $(100 \mathrm{MHz}): \delta 14.8\left(\mathrm{CH}_{3}\right), 52.1\left(\mathrm{CH}_{2}\right), 124.7,125.5,126.5,136.3,137.1$, 145.8. Anal. Calcd for $\mathrm{C}_{8} \mathrm{H}_{8} \mathrm{~N}_{4} \mathrm{O}_{2}$ (192.17): C, 50.00; H, 4.19; N, 29.16\%. Found: C, 50.26; H, $4.38 ; \mathrm{N}, 28.84 \%$.

The filtrate after the separation of compound 12 was diluted with water $(100 \mathrm{~mL})$ and refluxed for a short time. After cooling, it was extracted with dichloromethane (3 x $50 \mathrm{~mL})$. The combined organic layers were dried over $\mathrm{MgSO}_{4}$. The residue after evaporation of the solvent was chromatographed using hexane - ethyl acetate $3: 1$ as an eluent. The first fraction afforded $0.15 \mathrm{~g}$ of 1-ethyl-7-nitro-1 $\mathrm{H}$-benzotriazole (13) as yellow needles (ethanol), mp 98-99 ${ }^{\circ} \mathrm{C} .{ }^{1} \mathrm{H}$ NMR (400 MHz): $\delta 1.51\left(\mathrm{t},{ }^{3} J 7.1 \mathrm{~Hz}, 3 \mathrm{H}, \mathrm{CH}_{3}\right), 4.93\left(\mathrm{q},{ }^{3} \mathrm{~J} 7.1 \mathrm{~Hz}, 2 \mathrm{H}, \mathrm{CH}_{2}\right), 7.63\left(\mathrm{dd},{ }^{3} J_{45} 8.2\right.$ $\left.\mathrm{Hz},{ }^{3} J_{56} 7.9 \mathrm{~Hz}, 1 \mathrm{H}, 5-\mathrm{H}\right), 8.44\left(\mathrm{dd},{ }^{3} J_{56} 7.9 \mathrm{~Hz},{ }^{4} J_{46} 0.9 \mathrm{~Hz}, 1 \mathrm{H}, 6-\mathrm{H}\right), 8.58\left(\mathrm{dd},{ }^{3} J_{45} 8.2 \mathrm{~Hz},{ }^{4} J_{46}\right.$ $0.9 \mathrm{~Hz}, 1 \mathrm{H}, 4-\mathrm{H}) .{ }^{13} \mathrm{C} \mathrm{NMR}(100 \mathrm{MHz}): \delta 16.0\left(\mathrm{CH}_{3}\right), 47.0\left(\mathrm{CH}_{2}\right), 123.7,124.6,125.6,127.2$, 134.9, 148.5. Anal. Calcd for $\mathrm{C}_{8} \mathrm{H}_{8} \mathrm{~N}_{4} \mathrm{O}_{2}$ (192.17): C, 50.00; H, 4.19; N, 29.16\%. Found: C, $50.27 ; \mathrm{H}, 4.02 ; \mathrm{N}, 29.20 \%$. The third fraction was crystallized from ethanol to yield $0.49 \mathrm{~g}$ of compound 12, mp 101-102 ${ }^{\circ} \mathrm{C}$. 
Solid B (1.0 g) was chromatographed using hexane - ethyl acetate $3: 1$ as an eluent. The first fraction was crystallized from ethanol to yield $0.16 \mathrm{~g}$ of compound 13 (total yield: $0.31 \mathrm{~g}, 11 \%$ ). The third fraction after crystallization from ethanol afforded $0.09 \mathrm{~g}$ of compound $\mathbf{1 2}$ (total yield: $1.10 \mathrm{~g}, 38 \%)$. The fourth fraction was crystallized from ethanol to give $0.35 \mathrm{~g}$ (12\%) of 1-ethyl4-nitro- $1 H$-benzotriazole (11) as yellow plates, mp 146-147 ${ }^{\circ} \mathrm{C} .{ }^{1} \mathrm{H} \mathrm{NMR}(400 \mathrm{MHz}): \delta 1.56(\mathrm{t}$, $\left.{ }^{3} J 7.2 \mathrm{~Hz}, 3 \mathrm{H}, \mathrm{CH}_{3}\right), 4.87$ (q, $\left.{ }^{3} J 7.2 \mathrm{~Hz}, 2 \mathrm{H}, \mathrm{CH}_{2}\right), 7.80\left(\mathrm{dd},{ }^{3} J_{67} 8.2 \mathrm{~Hz},{ }^{3} J_{56} 7.7 \mathrm{~Hz}, 1 \mathrm{H}, 6-\mathrm{H}\right)$, $8.33\left(\mathrm{dd},{ }^{3} J_{56} 7.7 \mathrm{~Hz},{ }^{4} J_{57} 0.8 \mathrm{~Hz}, 1 \mathrm{H}, 5-\mathrm{H}\right), 8.47\left(\mathrm{dd},{ }^{3} J_{67} 8.2 \mathrm{~Hz},{ }^{4} J_{57} 0.8 \mathrm{~Hz}, 1 \mathrm{H}, 7-\mathrm{H}\right) .{ }^{13} \mathrm{C}$ NMR (100 MHz): $\delta 14.9\left(\mathrm{CH}_{3}\right), 43.5\left(\mathrm{CH}_{2}\right), 118.7,121.5,126.8,135.0,137.5,137.9$. Anal. Calcd for $\mathrm{C}_{8} \mathrm{H}_{8} \mathrm{~N}_{4} \mathrm{O}_{2}$ (192.17): C, 50.00; H, 4.19; N, 29.16\%. Found: C, 50.19; H, 4.35; N, $28.91 \%$.

Hydrogenation of 1-ethyl-7-nitro-1H-benzotriazole (13). A solution of compound 13 (116 mg, $0.6 \mathrm{mmol})$ in ethanol $(2 \mathrm{~mL})$ was added to a suspension of iron $(123 \mathrm{mg}, 2.2 \mathrm{mmol})$ in acetic acid ( $3 \mathrm{~mL}$ ). The resulted mixture was refluxed for 10 hours, ethanol was distilled off, and the residue was diluted with water $(10 \mathrm{~mL})$ and extracted with ethyl acetate $(2 \times 10 \mathrm{~mL})$. The combined extracts were dried over $\mathrm{MgSO}_{4}$, the solvent was removed and the residue was chromatographed using $\mathrm{CH}_{2} \mathrm{Cl}_{2}$ - methanol $10: 1$ as an eluent. Crystallization from dilute methanol afforded 52 $\mathrm{mg}(52 \%)$ of 7-amino-1-ethyl-1 $H$-benzotriazole (14) as beige needles, mp 53-54 ${ }^{\circ} \mathrm{C}$. ${ }^{1} \mathrm{H} \mathrm{NMR}$ (400 MHz): $\delta 1.46\left(\mathrm{t},{ }^{3} J 7.2 \mathrm{~Hz}, 3 \mathrm{H}, \mathrm{CH}_{3}\right), 4.89$ (q, ${ }^{3} \mathrm{~J} 7.2 \mathrm{~Hz}, 2 \mathrm{H}, \mathrm{CH}_{2}$ ), $5.54\left(\mathrm{~s}, 2 \mathrm{H}, \mathrm{NH}_{2}\right), 6.68$ $\left(\mathrm{dd},{ }^{3} J_{56} 7.5 \mathrm{~Hz},{ }^{4} J_{46} 0.7 \mathrm{~Hz}, 1 \mathrm{H}, 6-\mathrm{H}\right), 7.08\left(\mathrm{dd},{ }^{3} J_{45} 8.3 \mathrm{~Hz},{ }^{3} J_{56} 7.5 \mathrm{~Hz}, 1 \mathrm{H}, 5-\mathrm{H}\right), 7.21\left(\mathrm{dd},{ }^{3} J_{45}\right.$ $\left.8.3 \mathrm{~Hz},{ }^{4} J_{46} 0.7 \mathrm{~Hz}, 1 \mathrm{H}, 4-\mathrm{H}\right) .{ }^{13} \mathrm{C}$ NMR $(100 \mathrm{MHz}): \delta 17.0\left(\mathrm{CH}_{3}\right), 44.5\left(\mathrm{CH}_{2}\right), 107.0,110.3$, 124.1, 125.1, 134.2, 147.5. Anal. Calcd for $\mathrm{C}_{8} \mathrm{H}_{10} \mathrm{~N}_{4}$ (162.19): C, 59.24; H, 6.21; N, 34.55\%. Found: C, 59.13; H, 6.49; N, 34.38\%.

Vicarious nucleophilic substitution of hydrogen. Method A. Finely powdered KOH (400 mg) was added in one portion to a stirred solution of carbanion precursor 15 or 16 (1 mmol) and nitrobenzazole $(1 \mathrm{mmol})$ in dry DMSO $(5 \mathrm{~mL})$. The resulting dark coloured mixture was vigorously stirred for $30 \mathrm{~min}$ (unless otherwise stated) at $22{ }^{\circ} \mathrm{C}$, quenched with $3 \% \mathrm{HCl}(30 \mathrm{~mL})$ and extracted twice with $\mathrm{CH}_{2} \mathrm{Cl}_{2}(30$ and $20 \mathrm{~mL})$. The extract was washed with water, dried and the solvent was removed under vacuum. The purification procedure is given at the description of individual compounds.

Method B. A solution of carbanion precursor $15(1 \mathrm{mmol})$ and nitrobenzazole $(1 \mathrm{mmol})$ in dry DMF (4 mL) was added to a stirred solution of t-BuOK (336 mg, $3 \mathrm{mmol}$ ) in dry DMF (3 mL). The resulted mixture was stirred for $30 \mathrm{~min}$ (unless otherwise stated) at $-40{ }^{\circ} \mathrm{C}$, quenched with $3 \% \mathrm{HCl}(30 \mathrm{~mL})$ and extracted with $\mathrm{CH}_{2} \mathrm{Cl}_{2}(30$ and $20 \mathrm{~mL})$. The extract was washed with water, dried over $\mathrm{MgSO}_{4}$ and the solvent was removed under vacuum. The purification procedure is given at the description of individual compounds.

Method C. A solution of sulphone $15(1 \mathrm{mmol})$ and nitroarene $(1 \mathrm{mmol})$ in dry THF $(7 \mathrm{~mL})$ was added dropwise to a solution of t-BuOK $(336 \mathrm{mg}, 3 \mathrm{mmol})$ in dry THF $(3 \mathrm{~mL})$. The reaction was carried out as in method B.

1-Methyl-4-nitro-7-[1-(phenylsulfonyl)propyl]-1H-indazole (17). Method A. The residue was flash-chromatographed using hexanes - ethyl acetate $2: 1$ as an eluent to give compound $\mathbf{1 7}$ as 
yellow needles, $179 \mathrm{mg}(50 \%), \mathrm{mp} 179-181{ }^{\circ} \mathrm{C}$ (ethanol). ${ }^{1} \mathrm{H}$ NMR $(300 \mathrm{MHz}): \delta 0.79\left(\mathrm{t},{ }^{3} J 7.3\right.$ $\left.\mathrm{Hz}, 3 \mathrm{H}, \mathrm{CH}_{3} \mathrm{C}\right), 2.13-2.31\left(\mathrm{~m}, 2 \mathrm{H}, \mathrm{CH}_{2}\right), 4.38\left(\mathrm{~s}, 2 \mathrm{H}, \mathrm{CH}_{3} \mathrm{~N}\right), 5.41\left(\mathrm{dd},{ }^{3} J_{\text {syn }} 10.4 \mathrm{~Hz},{ }^{3} J_{\text {anti }} 4.7\right.$ $\mathrm{Hz}, 1 \mathrm{H}, \mathrm{CH}), 7.58-7.80(\mathrm{~m}, 6 \mathrm{H}, \mathrm{Ph}$ and $6-\mathrm{H}), 8.20\left(\mathrm{~d},{ }^{3} \mathrm{~J} 8.0 \mathrm{~Hz}, 1 \mathrm{H}, 5-\mathrm{H}\right), 8.53(\mathrm{~s}, 1 \mathrm{H}, 3-\mathrm{H}) .{ }^{13} \mathrm{C}$

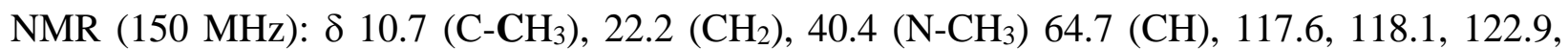
127.1, 128.9, 129.4, 131.1, 134.5, 136.4, 139.6, 140.6. Anal. Calcd for $\mathrm{C}_{17} \mathrm{H}_{17} \mathrm{~N}_{3} \mathrm{O}_{4} \mathrm{~S}$ (359.39): C, $56.81 ; \mathrm{H}, 4.77$; N, 11.69\%. Found: C, 57.04; H, 4.80; N, $11.52 \%$.

1-Ethyl-4-nitro-7-[1-(phenylsulfonyl)propyl]-1H-indazole (18). Method A. Reaction time: 50 min. The residue was flash-chromatographed using hexanes - ethyl acetate $3: 1$ as an eluent. Crystallization from $80 \%$ ethanol gave compound $\mathbf{1 8}$ as small yellow prisms, $132 \mathrm{mg}$ (35\%), mp 119-121 ${ }^{\circ} \mathrm{C} .{ }^{1} \mathrm{H}$ NMR $(300 \mathrm{MHz}): \delta 0.82\left(\mathrm{t},{ }^{3} \mathrm{~J} 7.4 \mathrm{~Hz}, 3 \mathrm{H}, \mathbf{C H}_{3} \mathrm{CH}_{2} \mathrm{C}\right), 1.43\left(\mathrm{t},{ }^{3} \mathrm{~J} 7.1 \mathrm{~Hz}, 3 \mathrm{H}\right.$, $\left.\mathbf{C H}_{3} \mathrm{CH}_{2} \mathrm{~N}\right), 2.24-2.33\left(\mathrm{~m}, 2 \mathrm{H}, \mathrm{CH}_{2} \mathrm{C}\right)$ 4.57-4.77 (m, $\left.2 \mathrm{H}, \mathrm{CH}_{2} \mathrm{~N}\right), 5.22\left(\mathrm{dd},{ }^{3} \mathrm{~J} 7.7\right.$ and $7.4 \mathrm{~Hz}, 1 \mathrm{H}$, $\mathrm{CH}), 7.57-7.78\left(\mathrm{~m}, 6 \mathrm{H}, \mathrm{Ph}\right.$ and 6-H), $8.20\left(\mathrm{~d},{ }^{3} \mathrm{~J} 8.2 \mathrm{~Hz}, 1 \mathrm{H}, 5-\mathrm{H}\right), 8.58(\mathrm{~s}, 1 \mathrm{H}, 3-\mathrm{H}) .{ }^{13} \mathrm{C}$ NMR $(100 \mathrm{MHz}): \delta 10.8\left(\mathrm{CH}_{3}\right), 15.3\left(\mathrm{CH}_{3}\right), 22.2\left(\mathrm{C}_{-} \mathrm{CH}_{2}\right) 47.0\left(\mathrm{~N}-\mathrm{CH}_{2}\right), 65.3(\mathrm{CH}), 117.8,118.1$, 122.8, 127.2, 129.0, 129.4, 131.7, 134.6, 136.2, 139.8, 139.9. MS m/z (\%): 373 (4), 233 (15), 232 (100, $\mathrm{M}-\mathrm{PhSO}_{2}$ ), 204 (4), 186 (6), 157 (4), 130 (3). Anal. Calcd for $\mathrm{C}_{18} \mathrm{H}_{19} \mathrm{~N}_{3} \mathrm{O}_{4} \mathrm{~S}$ (373.44): C, 57.89; H, 5.13; N, 11.25\%. Found: C, 58.01; H, 5.06; N, $11.50 \%$.

Method B. Reaction time: $20 \mathrm{~min}$. Purification procedure like in method A. Yield: $111 \mathrm{mg}$ $(30 \%)$.

1-Ethyl-4-nitro-5-p-toluenesulfonylmethyl-1 $H$-indazole (19) and 1-Ethyl-4-nitro-7-p-toluenesulfonylmethyl-1H-indazole (20). Method C. Reaction time: $60 \mathrm{~min}$. The residue was flashchromatographed using hexane - ethyl acetate 2: 1 as an eluent. Compound 20 (43 mg, $12 \%$ ) was obtained as orange plates, mp 201-203 ${ }^{\circ} \mathrm{C}$ (ethanol). ${ }^{1} \mathrm{H}$ NMR $(300 \mathrm{MHz}): \delta 1.47\left(\mathrm{t},{ }^{3} \mathrm{~J} 7.2\right.$ $\mathrm{Hz}, 3 \mathrm{H}, \mathbf{C H}_{3} \mathrm{CH}_{2}$ ), 2.43 (s, 3H, $\mathrm{CH}_{3} \mathrm{Ar}$ ), 4.71 (q, ${ }^{3} \mathrm{~J} 7.2 \mathrm{~Hz}, 2 \mathrm{H}, \mathrm{CH}_{2} \mathrm{~N}$ ), 5.29 (s, 2H, $\mathrm{CH}_{2} \mathrm{SO}_{2}$ ), 7.29 (d, $\left.{ }^{3} J 8.0 \mathrm{~Hz}, 1 \mathrm{H}, 6-\mathrm{H}\right), 7.44-7.46$ (m, 2H, Ts), 7.66-7.69 (m, 2H, Ts), 8.09 (d, ${ }^{3} J 8.0 \mathrm{~Hz}$, $1 \mathrm{H}, 5-\mathrm{H}), 8.61(\mathrm{~s}, 1 \mathrm{H}, 3-\mathrm{H}) .{ }^{13} \mathrm{C} \mathrm{NMR}(100 \mathrm{MHz}): \delta 15.2\left(\mathbf{C H}_{3} \mathrm{CH}_{2}\right), 21.1\left(\mathrm{CH}_{3} \mathrm{Ar}\right), 46.1$ $\left(\mathrm{CH}_{2} \mathrm{~N}\right), 57.8\left(\mathrm{CH}_{2} \mathrm{SO}_{2}\right), 117.7,117.8,119.4,128.3,129.9,131.5,131.8,135.1,139.2,139.9$, 145.1. Anal. Calcd for $\mathrm{C}_{17} \mathrm{H}_{17} \mathrm{~N}_{3} \mathrm{O}_{4} \mathrm{~S}$ (359.39): C, 56.81; H, 4.77; N, 11.69\%. Found: C, 57.02; H, 4.55; N, $11.49 \%$.

Compound 19 (156 mg, $43 \%$ ) was obtained as yellow needles, mp 167-168 ${ }^{\circ} \mathrm{C}$ (80\% ethanol). ${ }^{1} \mathrm{H}$ NMR (300 MHz): $\delta 1.42$ (t, ${ }^{3} \mathrm{~J} 7.1 \mathrm{~Hz}, 3 \mathrm{H}, \mathbf{C H}_{3} \mathrm{CH}_{2}$ ), 2.40 (s, 3H, $\mathrm{CH}_{3} \mathrm{Ar}$ ), 4.53 (q, ${ }^{3} \mathrm{~J} 7.1 \mathrm{~Hz}$, $\left.2 \mathrm{H}, \mathrm{CH}_{2} \mathrm{~N}\right), 5.26$ (s, 2H, $\mathrm{CH}_{2} \mathrm{SO}_{2}$ ), $7.36\left(\mathrm{~d},{ }^{3} J 8.7 \mathrm{~Hz}, 1 \mathrm{H}, 6-\mathrm{H}\right), 7.39-7.42$ (m, 2H, Ts), 7.53-7.57 (m, 2H, Ts), 8.12 (dd, $\left.{ }^{3} J 8.7 \mathrm{~Hz},{ }^{5} J 0.5 \mathrm{~Hz}, 1 \mathrm{H}, 7-\mathrm{H}\right), 8.29$ (d, $\left.{ }^{5} J 0.5 \mathrm{~Hz}, 1 \mathrm{H}, 3-\mathrm{H}\right) .{ }^{13} \mathrm{C}$ NMR (100 MHz): $\delta 14.8\left(\mathbf{C H}_{3} \mathrm{CH}_{2}\right), 21.1\left(\mathrm{CH}_{3} \mathrm{Ar}\right), 43.7\left(\mathrm{CH}_{2} \mathrm{~N}\right), 57.0\left(\mathrm{CH}_{2} \mathrm{SO}_{2}\right), 115.4,116.8,117.3$, 127.9, 129.9, 131.0, 131.6, 135.3, 140.1, 140.8, 144.8. Anal. Calcd for $\mathrm{C}_{17} \mathrm{H}_{17} \mathrm{~N}_{3} \mathrm{O}_{4} \mathrm{~S}$ (359.39): C, $56.81 ; \mathrm{H}, 4.77$; N, 11.69\%. Found: C, 56.87; H, 4.95; N, $11.83 \%$.

2-Ethyl-4-nitro-5-[1-(phenylsulfonyl)propyl]-2H-indazole (21) and 2-Ethyl-4-nitro-7-[1(phenylsulfonyl)propyl]-2H-indazole (22). Method A. The residue was flash-chromatographed using hexanes - ethyl acetate $2: 1$ as an eluent. The fraction containing compound 22 was treated with diethyl ether and the resulted solid was filtered off to give $178 \mathrm{mg}$ (49\%) of 22 as small yellow plates, mp $114-116{ }^{\circ} \mathrm{C} .{ }^{1} \mathrm{H}$ NMR (400 MHz): $\delta 0.81\left(\mathrm{t},{ }^{3} \mathrm{~J} 7.3 \mathrm{~Hz}, 3 \mathrm{H}, \mathbf{C H}_{3} \mathrm{CH}_{2} \mathrm{C}\right)$, 
$1.40\left(\mathrm{t},{ }^{3} \mathrm{~J} 7.3 \mathrm{~Hz}, 3 \mathrm{H}, \mathbf{C H}_{3} \mathrm{CH}_{2} \mathrm{~N}\right), 2.29-2.50\left(\mathrm{~m}, 2 \mathrm{H}, \mathrm{CH}_{2} \mathrm{C}\right)$ 4.37-4.47 (m, 2H, $\left.\mathrm{CH}_{2} \mathrm{~N}\right), 5.14$ (dd, $\left.{ }^{3} J_{\text {syn }} 11.3 \mathrm{~Hz},{ }^{3} J_{\text {anti }} 4.4 \mathrm{~Hz}, 1 \mathrm{H}, \mathrm{CH}\right), 7.34-7.54(2 \mathrm{x} \mathrm{m}, 5 \mathrm{H}, \mathrm{Ph}), 7.59$ (d, $\left.{ }^{3} J 8.0 \mathrm{~Hz}, 1 \mathrm{H}, 6-\mathrm{H}\right)$, $8.24\left(\mathrm{~d},{ }^{3} J 8.0 \mathrm{~Hz}, 1 \mathrm{H}, 5-\mathrm{H}\right), 8.78(\mathrm{~s}, 1 \mathrm{H}, 3-\mathrm{H}) .{ }^{13} \mathrm{C} \mathrm{NMR}(100 \mathrm{MHz}): \delta 11.2\left(\mathrm{CH}_{3}\right), 15.6\left(\mathrm{CH}_{3}\right)$, $20.7\left(\mathrm{C}^{-} \mathrm{CH}_{2}\right) 48.4\left(\mathrm{~N}-\mathrm{CH}_{2}\right), 65.8(\mathrm{CH}), 113.3,120.2,123.8,124.6,128.5,128.7,130.9,133.8$, 137.2, 139.7, 148.9. Anal. Calcd for $\mathrm{C}_{18} \mathrm{H}_{19} \mathrm{~N}_{3} \mathrm{O}_{4} \mathrm{~S}$ (373.44): C, 57.89; H, 5.13; N, 11.25\%. Found: C, 58.09; H, 5.28; N, 11.12\%.

Method B. Reaction time: $40 \mathrm{~min}$. LPLC and hexanes - ethyl acetate $2: 1$ as an eluent was used to separate the reaction mixture. Compound 22 (36 mg, 10\%) was obtained as yellow microcrystalline solid, mp 114-116 ${ }^{\circ} \mathrm{C}$. Compound 21 (91 mg, 25\%) was obtained as yellow prisms, mp 156-157 ${ }^{\circ} \mathrm{C}$ (ethanol). ${ }^{1} \mathrm{H}$ NMR (600 MHz): $\delta 0.82\left(\mathrm{t},{ }^{3} \mathrm{~J} 7.4 \mathrm{~Hz}, 3 \mathrm{H}, \mathbf{C H}_{3} \mathrm{CH}_{2} \mathrm{C}\right.$ ), $1.52\left(\mathrm{t},{ }^{3} \mathrm{~J} 7.3 \mathrm{~Hz}, 3 \mathrm{H}, \mathbf{C H}_{3} \mathrm{CH}_{2} \mathrm{~N}\right), 2.09-2.30\left(\mathrm{~m}, 2 \mathrm{H}, \mathrm{CH}_{2} \mathrm{C}\right) 4.50-4.56\left(\mathrm{~m}, 2 \mathrm{H}, \mathrm{CH}_{2} \mathrm{~N}\right), 5.41$ (dd, $\left.{ }^{3} J_{\text {syn }} 10.9 \mathrm{~Hz},{ }^{3} J_{\text {anti }} 4.3 \mathrm{~Hz}, 1 \mathrm{H}, \mathrm{CH}\right), 7.51-7.58(\mathrm{~m}, 5 \mathrm{H}, \mathrm{Ph}$ and 6-H), 7.67-7.70 (m, 1H, Ph), 8.11 $\left(\mathrm{d},{ }^{3} J 9.0 \mathrm{~Hz}, 1 \mathrm{H}, 7-\mathrm{H}\right), 8.61(\mathrm{~s}, 1 \mathrm{H}, 3-\mathrm{H}) .{ }^{13} \mathrm{C} \mathrm{NMR}(150 \mathrm{MHz}): \delta 10.9\left(\mathrm{CH}_{3}\right), 15.5\left(\mathrm{CH}_{3}\right), 20.9$ $\left(\mathrm{C}-\mathrm{CH}_{2}\right) 48.4\left(\mathrm{~N}-\mathrm{CH}_{2}\right), 64.5(\mathrm{CH}), 115.1,121.2,123.6,124.4,124.6,128.2,129.3,134.2,140.0$, 142.5, 148.0. MS m/z (\%): 373 (4), 233 (15), 232 (100, M - $\mathrm{PhSO}_{2}$ ), 204 (4), 186 (6), 157 (4), 130 (3). Anal. Calcd for $\mathrm{C}_{18} \mathrm{H}_{19} \mathrm{~N}_{3} \mathrm{O}_{4} \mathrm{~S}$ (373.44): C, 57.89; H, 5.13; N, 11.25\%. Found: C, 58.01; H, 5.06; N, $11.50 \%$.

1-Ethyl-7-nitro-4-[1-(phenylsulfonyl)propyl]-1H-indazole (23). Method A. Flashchromatography using hexanes - ethyl acetate $2: 1$ as an eluent afforded $148 \mathrm{mg}(40 \%)$ of compound 23 as light orange prisms, mp $134-135{ }^{\circ} \mathrm{C}$ (methanol). ${ }^{1} \mathrm{H}$ NMR $(300 \mathrm{MHz}): \delta 0.76(\mathrm{t}$, ${ }^{3} J 7.4 \mathrm{~Hz}, 3 \mathrm{H}, \mathbf{C H}_{3} \mathrm{CH}_{2} \mathrm{C}$ ), 1.27 (t, $\left.{ }^{3} \mathrm{~J} 7.1 \mathrm{~Hz}, 3 \mathrm{H}, \mathbf{C H}_{3} \mathrm{CH}_{2} \mathrm{~N}\right), 2.20-2.36\left(\mathrm{~m}, 2 \mathrm{H}, \mathrm{CH}_{2} \mathrm{C}\right) 4.42$ (q, $\left.{ }^{3} J 7.1 \mathrm{~Hz}, 2 \mathrm{H}, \mathrm{CH}_{2} \mathrm{~N}\right), 5.28\left(\mathrm{dd},{ }^{3} J_{\text {syn }} 10.4 \mathrm{~Hz},{ }^{3} J_{\text {anti }} 4.7 \mathrm{~Hz}, 1 \mathrm{H}, \mathrm{CH}\right), 7.36\left(\mathrm{~d},{ }^{3} J 8.0 \mathrm{~Hz}, 1 \mathrm{H}, 5-\right.$ H), 7.44-7.49 (m, 2H, Ph), 7.56-7.66 (m, 3H, Ph), 8.20 (d, $\left.{ }^{3} J 8.0 \mathrm{~Hz}, 1 \mathrm{H}, 6-\mathrm{H}\right), 8.50$ (s, 1H, 3-H). ${ }^{13} \mathrm{C}$ NMR $(150 \mathrm{MHz}): \delta 10.8\left(\mathrm{CH}_{3}\right), 15.1\left(\mathrm{CH}_{3}\right), 21.0\left(\mathrm{C}_{-} \mathrm{CH}_{2}\right) 47.3\left(\mathrm{~N}-\mathrm{CH}_{2}\right), 67.1(\mathrm{CH}), 120.0$, $124.5,128.5,129.0,129.9,133.4,133.8,134.0,134.5,136.9$. As one quaternary signal was missing, the ${ }^{13} \mathrm{C}$ NMR spectrum $(150 \mathrm{MHz})$ was additionally registered in acetone- $\mathrm{d}_{6}: \delta 11.4$ $\left(\mathbf{C H}_{3} \mathrm{CH}_{2} \mathrm{C}\right), 15.6\left(\mathbf{C H}_{3} \mathrm{CH}_{2} \mathrm{~N}\right), 22.3\left(\mathbf{C H}_{2} \mathrm{C}\right), 48.5\left(\mathrm{CH}_{2} \mathrm{~N}\right), 69.4(\mathrm{CH}), 121.1,125.0,129.1$, 129.7, 130.3, 131.2, 134.1, 134.66, 134.70, 136.0, 138.7. Anal. Calcd for $\mathrm{C}_{18} \mathrm{H}_{19} \mathrm{~N}_{3} \mathrm{O}_{4} \mathrm{~S}$ (373.44): C, 57.89; H, 5.13; N, 11.25\%. Found: C, 58.11; H, 5.01; N, $11.40 \%$.

Method B. Purification as in method A afforded $117 \mathrm{mg}(31 \%)$ of compound 23.

1-Ethyl-4-nitro-7-[1-(phenylsulfonyl)propyl]-1H-benzotriazole (24). Method A. Flashchromatography using hexanes - ethyl acetate 1:2 as an eluent gave $175 \mathrm{mg}(46 \%)$ of compound 24 as pale yellow needles, mp 160-162 ${ }^{\circ} \mathrm{C}$ (ethanol). ${ }^{1} \mathrm{H}$ NMR $(400 \mathrm{MHz}): \delta 0.83(\mathrm{t}$, $\left.{ }^{3} J 7.4 \mathrm{~Hz}, 3 \mathrm{H}, \mathbf{C H}_{3} \mathrm{CH}_{2} \mathrm{C}\right), 1.56\left(\mathrm{t},{ }^{3} \mathrm{~J} 7.2 \mathrm{~Hz}, 3 \mathrm{H}, \mathbf{C H}_{3} \mathrm{CH}_{2} \mathrm{~N}\right), 2.24-2.36\left(\mathrm{~m}, 2 \mathrm{H}, \mathrm{CH}_{2} \mathrm{C}\right) 4.84-$ $4.99\left(\mathrm{~m}, 2 \mathrm{H}, \mathrm{CH}_{2} \mathrm{~N}\right), 5.21\left(\mathrm{dd},{ }^{3} J_{\text {syn }} 8.9 \mathrm{~Hz},{ }^{3} J_{\text {anti }} 6.4 \mathrm{~Hz}, 1 \mathrm{H}, \mathrm{CH}\right), 7.57-7.66(\mathrm{~m}, 4 \mathrm{H}, \mathrm{Ph}), 7.72$ $\left(\mathrm{d},{ }^{3} \mathrm{~J} 8.4 \mathrm{~Hz}, 1 \mathrm{H}, 6-\mathrm{H}\right), 7.72-7.78(\mathrm{~m}, 1 \mathrm{H}, \mathrm{Ph}), 8.33\left(\mathrm{~d},{ }^{3} \mathrm{~J} 8.4 \mathrm{~Hz}, 1 \mathrm{H}, 5-\mathrm{H}\right) .{ }^{13} \mathrm{C}$ NMR $(100$ MHz): $\delta 10.7\left(\mathrm{CH}_{3}\right), 15.3\left(\mathrm{CH}_{3}\right), 21.9\left(\mathrm{C}_{-} \mathrm{CH}_{2}\right) 45.9\left(\mathrm{~N}-\mathrm{CH}_{2}\right), 65.3(\mathrm{CH}), 121.2,123.4,128.1$, 129.1, 129.4, 134.68, 134.74, 135.8, 138.1, 138.3. Anal. Calcd for $\mathrm{C}_{17} \mathrm{H}_{18} \mathrm{~N}_{4} \mathrm{O}_{4} \mathrm{~S}$ (374.41): C, 54.53 ; H, 4.85; N, 14.96\%. Found: C, 54.28; H, 4.99; N, $14.76 \%$. 
Method B. Flash-chromatography using hexanes - ethyl acetate $2: 1$ as an eluent gave $133 \mathrm{mg}$ (35\%) of compound 24.

2-Ethyl-4-nitro-5-[1-(phenylsulfonyl)propyl]-2H-benzotriazole (25) and 2-ethyl-4-nitro-7[1-(phenylsulfonyl)propyl]-2H-benzotriazole (26). Method A. The residue was chromatographed using hexanes - ethyl acetate $1: 2$ as an eluent to yield $215 \mathrm{mg}(55 \%)$ of compound 26 as pale yellow needles, mp 134-136 ${ }^{\circ} \mathrm{C}$ (ethanol). ${ }^{1} \mathrm{H}$ NMR (400 MHz): $\delta 0.83(\mathrm{t}$, ${ }^{3} J 7.2 \mathrm{~Hz}, 3 \mathrm{H}, \mathbf{C H}_{3} \mathrm{CH}_{2} \mathrm{C}$ ), $1.51\left(\mathrm{t},{ }^{3} \mathrm{~J} 7.1 \mathrm{~Hz}, 3 \mathrm{H}, \mathbf{C H}_{3} \mathrm{CH}_{2} \mathrm{~N}\right.$ ), 2.44 (quintet, $2 \mathrm{H}, \mathrm{CH}_{2} \mathrm{C}$ ) 4.74 (q, $\left.{ }^{3} J 7.1 \mathrm{~Hz}, 2 \mathrm{H}, \mathrm{CH}_{2} \mathrm{~N}\right), 5.11\left(\mathrm{dd},{ }^{3} J 7.7\right.$ and $\left.7.4 \mathrm{~Hz}, 1 \mathrm{H}, \mathrm{CH}\right), 7.39-7.61(3 \mathrm{x} \mathrm{m}, 5 \mathrm{H}, \mathrm{Ph}), 7.73(\mathrm{~d}$, $\left.{ }^{3} J 8.1 \mathrm{~Hz}, 1 \mathrm{H}, 6-\mathrm{H}\right), 8.51\left(\mathrm{~d},{ }^{3} J 8.1 \mathrm{~Hz}, 1 \mathrm{H}, 5-\mathrm{H}\right) .{ }^{13} \mathrm{C} \mathrm{NMR}(100 \mathrm{MHz}): \delta 11.1\left(\mathrm{CH}_{3}\right), 14.7$ $\left(\mathrm{CH}_{3}\right), 20.4\left(\mathrm{C}_{-} \mathrm{CH}_{2}\right) 52.1\left(\mathrm{~N}-\mathrm{CH}_{2}\right), 67.4(\mathrm{CH}), 124.6,125.8,128.7,128.9,131.5,134.0,135.8$, 136.8, 136.9, 145.8. Anal. Calcd for $\mathrm{C}_{17} \mathrm{H}_{18} \mathrm{~N}_{4} \mathrm{O}_{4} \mathrm{~S}$ (374.41): C, 54.53; H, 4.85; N, 14.96\%. Found: C, 54.59; H, 4.62; N, 14.79\%.

Method B. The residue was chromatographed using hexanes - ethyl acetate $4: 1$ as an eluent to yield $150 \mathrm{mg}(38 \%)$ of compound 25 as small yellow plates, mp $107-109{ }^{\circ} \mathrm{C}$ (ethanol-hexanes). ${ }^{1} \mathrm{H}$ NMR (400 MHz): $\delta 0.80\left(\mathrm{t},{ }^{3} \mathrm{~J} 7.4 \mathrm{~Hz}, 3 \mathrm{H}, \mathbf{C H}_{3} \mathrm{CH}_{2} \mathrm{C}\right), 1.61\left(\mathrm{t},{ }^{3} \mathrm{~J} 7.2 \mathrm{~Hz}, 3 \mathrm{H}, \mathbf{C H}_{3} \mathrm{CH}_{2} \mathrm{~N}\right)$, 2.22-2.36 (m, 2H, $\left.\mathrm{CH}_{2} \mathrm{C}\right) 4.86\left(\mathrm{q},{ }^{3} J 7.2 \mathrm{~Hz}, 2 \mathrm{H}, \mathrm{CH}_{2} \mathrm{~N}\right), 4.90\left(\mathrm{dd},{ }^{3} J_{\text {syn }} 10.9 \mathrm{~Hz},{ }^{3} J_{\text {anti }} 4.4 \mathrm{~Hz}\right.$, $1 \mathrm{H}, \mathrm{CH}), 7.53-7.76(2 \times \mathrm{m}+\mathrm{d}, 6 \mathrm{H}, \mathrm{Ph}+6-\mathrm{H}), 8.39\left(\mathrm{~d},{ }^{3} J 9.0 \mathrm{~Hz}, 1 \mathrm{H}, 7-\mathrm{H}\right) .{ }^{13} \mathrm{C} \mathrm{NMR}(100$ $\mathrm{MHz}): \delta 10.8\left(\mathrm{CH}_{3}\right), 14.6\left(\mathrm{CH}_{3}\right), 21.0\left(\mathrm{C}_{-} \mathrm{CH}_{2}\right) 52.2\left(\mathrm{~N}-\mathrm{CH}_{2}\right), 65.0(\mathrm{CH}), 123.0,123.8,125.4$, 128.4, 129.5, 134.5, 136.2, 136.6, 140.0, 144.6. Anal. Calcd for $\mathrm{C}_{17} \mathrm{H}_{18} \mathrm{~N}_{4} \mathrm{O}_{4} \mathrm{~S}$ (374.41): C, 54.53; H, 4.85; N, 14.96\%. Found: C, 54.80; H, 4.58; N, 14.84\%.

The fraction containing a mixture of isomers $\mathbf{2 5}$ and $\mathbf{2 6}$ was not further separated.

1-Ethyl-7-nitro-4-[1-(phenylsulfonyl)propyl]-1H-benzotriazole (27). Method A. The residue was chromatographed using hexanes - ethyl acetate $1: 2$ as an eluent to yield $230 \mathrm{mg}(59 \%)$ of compound 27 as pale yellow needles, mp 143-145 ${ }^{\circ} \mathrm{C}$ (ethanol). ${ }^{1} \mathrm{H}$ NMR $(400 \mathrm{MHz}): \delta 0.79(\mathrm{t}$, ${ }^{3}$ J $7.4 \mathrm{~Hz}, 3 \mathrm{H}, \mathbf{C H}_{3} \mathrm{CH}_{2} \mathrm{C}$ ), 1.45 (t, $\left.{ }^{3} \mathrm{~J} 7.2 \mathrm{~Hz}, 3 \mathrm{H}, \mathbf{C H}_{3} \mathrm{CH}_{2} \mathrm{~N}\right), 2.34-2.47$ (m, 2H, CH$\left.{ }_{2} \mathrm{C}\right) 4.87$ (q, $\left.{ }^{3} J 7.2 \mathrm{~Hz}, 2 \mathrm{H}, \mathrm{CH}_{2} \mathrm{~N}\right), 5.40\left(\mathrm{dd},{ }^{3} J_{\text {syn }} 9.6 \mathrm{~Hz},{ }^{3} J_{\text {anti }} 6.0 \mathrm{~Hz}, 1 \mathrm{H}, \mathrm{CH}\right), 7.44-7.64(2 \mathrm{x} \mathrm{m}, 5 \mathrm{H}, \mathrm{Ph})$, $7.68\left(\mathrm{~d},{ }^{3} \mathrm{~J} 8.1 \mathrm{~Hz}, 1 \mathrm{H}, 5-\mathrm{H}\right), 8.48\left(\mathrm{~d},{ }^{3} \mathrm{~J} 8.1 \mathrm{~Hz}, 1 \mathrm{H}, 6-\mathrm{H}\right) .{ }^{13} \mathrm{C} \mathrm{NMR}(100 \mathrm{MHz}): \delta 11.1\left(\mathrm{CH}_{3}\right)$, $15.9\left(\mathrm{CH}_{3}\right), 20.9\left(\mathrm{C}-\mathrm{CH}_{2}\right) 47.1\left(\mathrm{~N}-\mathrm{CH}_{2}\right), 66.0(\mathrm{CH}), 123.4,124.2,125.5,128.5,129.1,132.1$, 134.1, 134.7, 136.7, 148.5. Anal. Calcd for $\mathrm{C}_{17} \mathrm{H}_{18} \mathrm{~N}_{4} \mathrm{O}_{4} \mathrm{~S}$ (374.41): C, 54.53; H, 4.85; N, $14.96 \%$. Found: C, 54.69; H, 4.76; N, 15.17\%.

X-ray structure analysis of 18. Crystal data for $\mathrm{C}_{18} \mathrm{H}_{19} \mathrm{~N}_{3} \mathrm{O}_{4} \mathrm{~S}$ : monoclinic, space group Cc, $a=13.5565(6) \AA, b=15.689(3) \AA, c=8.1832(3), \beta=97.851(3), V=1712.90(12) \AA, Z=1, \lambda=0.71073$ $\AA$. Data were collected at $130 \mathrm{~K}$ for a crystal with dimensions 0.25 x 0.2 x $0.1 \mathrm{~mm}$ with a KM4CCD Oxford diffractometer using graphite monochromated Mo Ka radiation. Cell parameters were obtained from 2852 independent reflections. The crystal structures have been solved with the SHELXS-97 and refined with the SHELXL-97 program packages. $^{22}$

Crystallographic data for the structure of $\mathbf{1 8}$ in CIF format have been deposited at the Cambridge Crystallographic Data Centre and allocated the deposition number CCDC 869881. 
Theoretical calculations. Density functional calculations were executed and the geometries of compounds were optimized at the DFT level of theory using the Gaussian 09 program, ${ }^{23}$ B3LYP functional, 6-31 G (d,p) basis set, and Conductor-like Polarizable Continuum Model (CPCM, DMSO as solvent). ${ }^{23-26}$ NBO calculations were carried out as implemented in the Gaussian 09.

\section{Acknowledgements}

The computations were supported by PCSS (Poznan Supercomputing Center) Grant No 92/2011.

\section{References}

1. Mąkosza, M.; Wojciechowski, K. Chem. Rev. 2004, 104, 2631.

2. Donskaya, O. V.; Dolgushin, G. V.; Lopyrev, V. A. Chem. Heterocycl. Comp. 2002, 38, 371.

3. Larina, L.; Lopyrev, V. Nitroazoles: Synthesis, Structure and Applications, Springer: Dordrecht, 2009.

4. Mąkosza, M.; Wojciechowski, K. Liebigs Ann./Recueil 1997, 1805.

5. Mąkosza, M.; Wojciechowski, K. Heterocycles 2001, 54, 445.

6. Liu, K. G.; Robichaud, A. J.; Greenfield, A. A.; Lo, J. R.; Grosanu, C.; Mattes, J. F.; Cai, Y.; Zhang, G. M.; Zhang, J. Y.; Kowal, D. M.; Smith, D. L.; Di, L.; Kerns, E. H.; Schechter, L. E.; Comery, T. A. Biorg. Med. Chem. 2011, 19, 650.

7. Bernard, M. K.; Kujawski, J.; Janusz, A.; Kuźma, W.; Rybczyńska, M.; Totoń, E.; Wierzchowski, M. Synthesis of some fused heteroaromatic compounds with potential antitumor activity, 5th Polish-German Symposium, Poznań 2009, p.29.

8. Kujawski, J.; Skierska, U.; Bernard, M. K.; Kurczab, R.; Bojarski, A. unpublished data.

9. Bernard, M. K. Tetrahedron 2000, 56, 7273.

10. Bernard, M. K. Pol. J. Chem. 2001, 75, 1465.

11. Seeliger, F.; Błażej, S.; Bernhardt, S.; Mąkosza, M.; Mayr, H. Chem. Eur. J. 2008, 14, 6108.

12. Błażej, S.; Mąkosza, M. Chem. Eur. J. 2008, 14, 11113.

13. Larina, L. I.; Milata, V. Magn. Res. Chem. 2009, 47, 142.

14. Bernard, M. K.; Szoja, C.; Wrzeciono, U. Liebigs Ann. Chem. 1990, 755.

15. Domenicano, A.; Schultz, G.; Hargittai, I.; Colapietro, M.; Portalone, G.; George, P.; Bock, C. W. Struct. Chem. 1989, 1, 107.

16. Desiraju, G. R.; Steiner, T. The Weak Hydrogen Bond in Structural Chemistry and Biology, Oxford University Press: New York 1999, p 13.

17. Desiraju, G. R.; Steiner, T. The Weak Hydrogen Bond in Structural Chemistry and Biology, Oxford University Press: New York 1999, p 8.

18. von Auwers, K.; Frese, E. Ber. 1925, 35B, 1369. 
19. Mąkosza, M.; Goliński, J.; Baran, J. J. Org. Chem. 1984, 49, 1488.

20. Cheung, M.; Boloor, A.; Stafford, J. A. J. Org. Chem. 2003, 43, 4093.

21. Noelting, E. Ber. 1904, 37, 2556.

22. Sheldrick, G. M. SHELX-97, a program for crystal structure determination, University of Göttingen, Germany, 1998.

23. Gaussian 09, Revision A.1 Frisch, M. J.; Trucks, G. W.; Schlegel, H. B.; Scuseria, G. E.; Robb, M. A.; Cheeseman, J. R.; Scalmani, G.; Barone, V.; Mennucci, B.; Petersson, G. A.; Nakatsuji, H.; Caricato, M.; Li, X.; Hratchian, H. P.; Izmaylov, A. F.; Bloino, J.; Zheng, G.; Sonnenberg, J. L.; Hada, M.; Ehara, M.; Toyota, K.; Fukuda, R.; Hasegawa, J.; Ishida, M.; Nakajima, T.; Honda, Y.; Kitao, O.; Nakai, H.; Vreven, T.; Montgomery, Jr., J. A.; Peralta, J. E.; Ogliaro, F.; Bearpark, M.; Heyd, J. J.; Brothers, E.; Kudin, K. N.; Staroverov, V. N.; Kobayashi, R.; Normand, J.; Raghavachari, K.; Rendell, A.; Burant, J. C.; Iyengar, S. S.; Tomasi, J.; Cossi, M.; Rega, N.; Millam, N. J.; Klene, M.; Knox, J. E.; Cross, J. B.; Bakken, V.; Adamo, C.; Jaramillo, J.; Gomperts, R.; Stratmann, R. E.; Yazyev, O.; Austin, A. J.; Cammi, R.; Pomelli, C.; Ochterski, J. W.; Martin, R. L.; Morokuma, K.; Zakrzewski, V. G.; Voth, G. A.; Salvador, P.; Dannenberg, J. J.; Dapprich, S.; Daniels, A. D.; Farkas, Ö.; Foresman, J. B.; Ortiz, J. V.; Cioslowski, J.; Fox, D. J. Gaussian, Inc., Wallingford CT, 2009.

24. Becke, A. D. J. Chem. Phys. 1993, 98, 5648.

25. Lee, C.; Yang, W.; Parr, R. G. Phys. Rev. B 1988, 37, 785.

26. Eckert, F.; Klamt, A. AlChE J. 2002, 48, 369.

\section{Graphical Abstract}

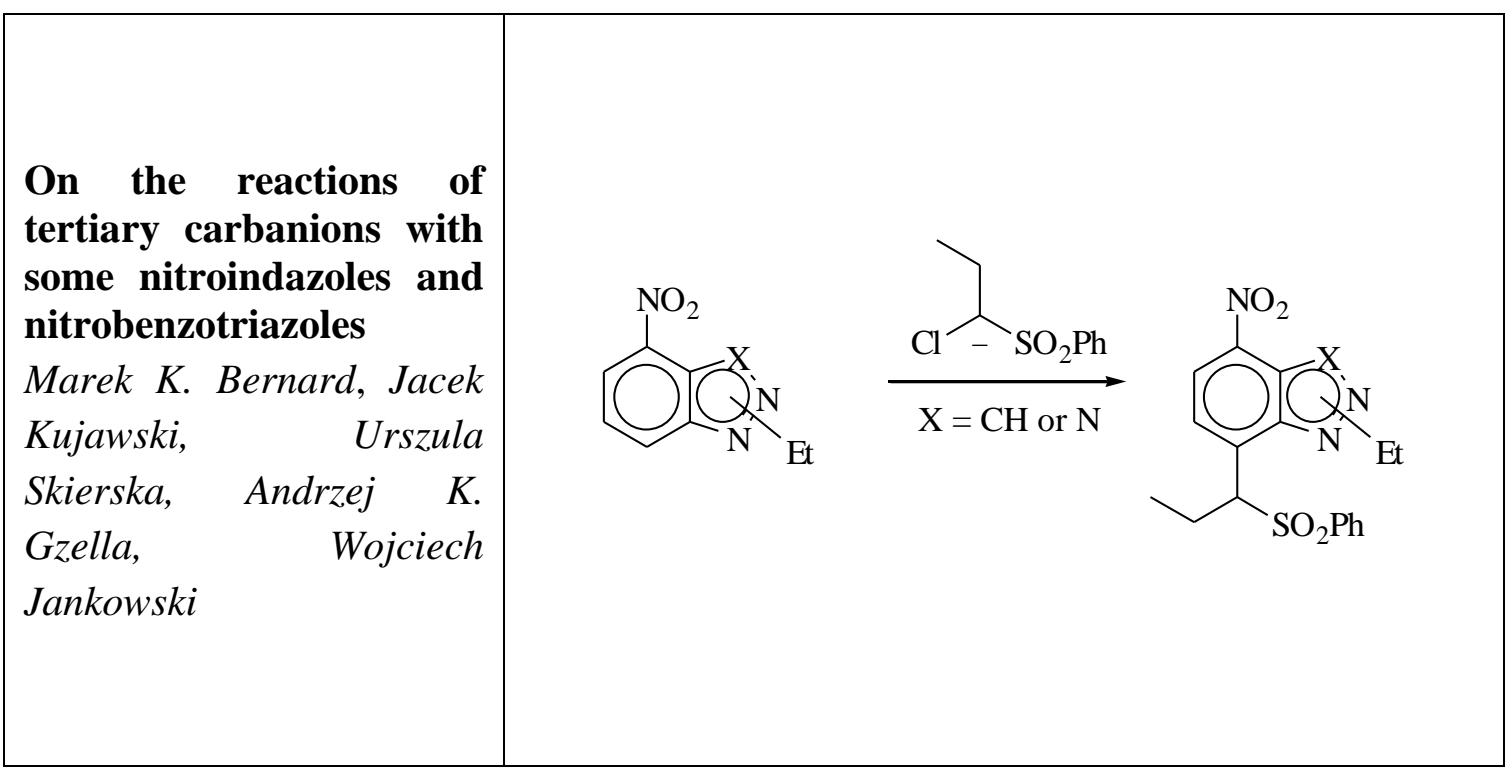

